\title{
Poemas na mídia podcast - uma proposta para 0 trabalho com oralidade nas aulas de língua portuguesa como língua materna
}

\author{
Poemas de podcast - una propuesta para trabajar con la \\ oralidad en las clases de portugués como lengua materna
}

\section{Poems in the podcast midia - a proposal for working with orality in portuguese classes as mother language}

\author{
Claudia Lopes Pontara* \\ Andressa Aparecida Lopes ${ }^{1 * *}$
}

\begin{abstract}
RESUMO: Este estudo objetiva apresentar uma proposta de trabalho em Língua Materna por meio de uma Sequência Didática - SD, elaborada com base no gênero poema, mais especificamente, a quadra, a cinquina e o biopoema (ramificações do gênero poema, aos quais denominaremos de subgêneros), em uma interface com a mídia podcast, via declamação dos poemas produzidos, envolvendo temáticas de cunho pessoal, como família e amizade. Para tanto, a pesquisa alicerça-se nos pressupostos teóricos acerca das novas tecnologias e ensino (ROJO, 2012; DIONÍSIO, 2011; PRENSKY, 2001), nas contribuições acerca do podcast enquanto mídia e instrumento pedagógico (FREIRE, 2010, 2013; RIBEIRO, 2009; LEVY, 1999), nas considerações teórico-metodológicas do Interacionismo Sociodiscursivo -ISD acerca dos gêneros de textos (BRONCKART, [1999] 2012, 2008) e do ensino com base em gêneros de texto por meio do procedimento SD (DOLZ, NOVERRAZ, SCHNEUWLY, [2004]2010). No que diz respeito à metodologia empregada, trata-se de um estudo qualitativo-interventivo, visando à elaboração de uma SD que contemple práticas de oralidade alinhadas às práticas de leitura e escrita. Dessa forma, a proposta em questão pretende permitir que os alunos possam falar de si, por meio de práticas sociais efetivas, utilizando-se de recursos tecnológicos.
\end{abstract}

PALAVRAS-CHAVE: Mídia podcast; poema; oralidade; sequência didática

*Doutoranda do PPGEL - Programa de Pós-Graduação em Estudos da Linguagem da Universidade Estadual de Londrina (UEL). Professora de Língua Inglesa - Secretaria de Estado da Educação do Paraná - SEED. clpontara@gmail.com

** Doutoranda do PPGEL - Programa de Pós-Graduação em Estudos da Linguagem da Universidade Estadual de Londrina (UEL). Professora do curso de Letras - UNOPAR. dressalopes@hotmail.com 
RESUMEN: Este estudio tiene como objetivo presentar una propuesta de trabajo en Lengua Materna por medio de una Secuencia Didáctica - SD, elaborada con base en el género poema, más específicamente, el cuarteto, la cinquina y el biopoema (ramificaciones del género poema, a los cuales denominaremos subgéneros) en una interfaz con los el medio de comunicación podcast, a través de la declamación de los poemas producidos, envolviendo temáticas de carácter personal, como la familia y la amistad. La investigación se fundamenta en los presupuestos teóricos acerca de las nuevas tecnologías y enseñanza (ROJO, 2012, DIONISIO, 2011, PRENSKY, 2001), y las contribuciones acerca del podcast como medios e instrumento pedagógico (FREIRE, 2010, 2013, RIBEIRO, 2009: LEVY, 1999), en las consideraciones teóricometodológicas del Interaccionismo Sociodiscursivo - ISD sobre los géneros de textos (BRONCKART, [1999] 2012, 2008) y de la enseñanza basada en géneros de texto a través del procedimiento SD (DOLZ, NOVERRAZ , SCHNEUWLY, [2004] 2010). La metodología empleada, se trata de un estudio cualitativo-interventivo, buscando la elaboración de una SD que contemple prácticas de la oralidad ya las prácticas de lectura y escritura. De esta forma, la propuesta en cuestión possibilitará que los alumnos puedan hablar de sí mismos, por medio de las prácticas sociales efectivas, utilizando los recursos tecnológicos.

PALABRAS CLAVE: Podcast; poema; oralidad; secuencia didáctica

ABSTRACT: This study aims to present a proposal of work in Mother Language through a Didactic Sequence - DS, based on the text genre poem, more specifically the quadra, cinquain and biopoem (ramifications of the genre poem, which we will call subgenres), in an interface with podcast media, through the recitation of the produced poems, involving personal themes such as family and friendship. For this, the research is based on the theoretical assumptions about the new technologies and teaching (ROJO, 2012; DIONÍSIO, 2011; PRENSKY, 2001), on the contributions about the podcast as a media and pedagogical instrument (Freire, 2010, 2009), on the theoretical-methodological considerations of Sociodiscursive Interactionism (SDI) (BRONCKART, [2004] 2010) and on the teaching based on genres of text through the DS procedure (DOLZ, NOVERRAZ, SCHNEUWLY, [2004]2010). With regard to the methodology used, it is a qualitative-intervention study, aiming at the elaboration of an DS that contemplates orality practices aligned with the practices of reading and writing. Thus, the proposal in question aims to enable students to talk about themselves, through effective social practices, using technological resources.

KEY WORDS: Media podcast; poem; orality; didactic sequence

\section{Introdução}

Desde o início da década de 1980, vem se re(discutindo), frequentemente, as propostas metodológicas da prática de ensinar/aprender línguas. Ainda no período apontado, com a democratização da educação, a escola - e consequentemente suas práticas - se transformam. No que diz 
respeito ao ensino de Língua Materna, a concepção interacionista de linguagem começa a ser observada mediante obras que enfatizavam um novo olhar para a área científica da linguagem. A publicação do livro "Portos de Passagem", de Wanderley Geraldi (1984) já apontava para essa nova perspectiva e, posteriormente, a publicação dos Parâmetros Curriculares Nacionais de Língua Portuguesa - PCN (BRASIL, 1998) também o fez.

Têm sido décadas de estudos voltados para o objeto de ensino que parta da prática social efetiva do aluno/cidadão. Dentre as principais correntes teóricas dessa época, encontram-se o interacionismo sociodiscursivo (BRONCKART) - perpassado pelas obras de Bakhtin/Voloshinov, os Novos Estudos do Letramento - divididos em amplas discussões e vertentes de vários teóricos como Street, Kleiman, Soares e Rojo - e mais adiante, que acaba se consolidando como a atual grande discussão, os estudos acerca dos multiletramentos, letramentos digitais e as novas tecnologias.

Nesse contexto, no qual gerações distintas utilizam-se das novas tecnologias digitais para todas as suas atividades e, consequentemente, realizam suas práticas de leitura, escrita e oralidade por meio das Tecnologias Digitais de Informação e Comunicação - TDIC, é evidente que a escola tente realizar o mesmo diálogo.

Dentro da perspectiva apresentada, o presente trabalho pretende contribuir para com essa cadeia de estudos teóricos e práticos que visam tratar a tecnologia não como salvadora da educação, mas como um instrumento norteador de grande importância pedagógica e social, devendo, por tal motivo, fazer parte das práticas escolares que, nada mais são do que um reflexo imediato das práticas sociais existentes.

Para tanto, nosso objetivo principal é apresentar uma proposta pedagógica com base no gênero poema em uma interface com a mídia podcast, destinada a alunos de $6^{\circ}$ ano do Ensino Fundamental. Pautamo-nos no 
procedimento SD de forma a considerar um gênero de texto (o poema) em três de seus subgêneros²: a quadra, a cinquina e o biopoema ${ }^{3}$.

Entendemos que o trabalho com esses três subgêneros pode vir a contribuir para que alunos do ensino fundamental II se expressem de forma mais aberta e espontânea de modo a promover um ambiente de aprendizagem mais prazeroso e também mais lúdico, visto que são alunos recém-chegados do Ensino Fundamental I. E essa ruptura, presente entre as duas etapas do Ensino Fundamental, não raro, tem sido sentida como um entrave para o sucesso desses alunos nessa nova etapa de ensino.

Assim, a SD aqui apresentada torna-se um instrumento voltado para o ensino de Língua Materna, com um viés interdisciplinar e que, ainda, permite associar-se a um recurso tecnológico (o podcast) presente no cotidiano dos alunos com vistas a propiciar meios para que os discentes continuem tendo, nessa etapa do ensino fundamental, um ambiente aberto para se expressarem, para (con)viverem com colegas e professores.

\section{Novas tecnologias e (multi)letramentos - estabelecendo relações}

Como reitera Dionísio (2011), falar que a sociedade vivencia as novas tecnologias é afirmar o óbvio. Contudo, ainda de acordo com os preceitos da autora, a necessidade de revisitar os estudos teóricos e metodológicos das práticas pedagógicas parece ser uma emergência.

\footnotetext{
${ }^{2}$ Sousa (2013), em sua tese de doutoramento, trata de questões relacionadas ao letramento literário na escola por meio do estudo do poema nas aulas de Língua Portuguesa no Ensino Médio. $\mathrm{O}$ autor optou, nesse estudo, por trabalhar com o soneto, o poema em prosa e a canção - letra de música, aos quais ele denominou de subgêneros. Apoiamo-nos, portanto, em Sousa (2013) para tratarmos a quadra, a cinquina e o biopoema também como subgêneros do gênero poema.

${ }^{3}$ Os subgêneros cinquina (cinquin) e biopoema (biopoem) são muito frequentes em língua inglesa. Assim, pelo fato de uma das autoras deste artigo atuar como professora de língua inglesa na educação básica, tal conhecimento foi trazido para o contexto de ensino de língua materna. Dessa forma, havendo as condições e o interesse, ao se implementar a SD aqui apresentada será possível realizar um trabalho interdisciplinar com a língua inglesa, o que resultaria em produções bilíngues, propiciando um maior envolvimento dos alunos e dos professores.
} 
A grande transformação no acesso à internete nos dispositivos móveis antes computadores de mesa e agora notebooks, tablets e smartphones permitiu que a mobilidade e a conexão em rede se tornasse algo instantâneo e indiscriminado. $\mathrm{O}$ que há vinte anos só era possível de se realizar em escritórios e residências, hoje, materializa-se em qualquer lugar. Isso permite com que a conexão com grupos distintos e a busca de informações se torne cada vez mais ágil.

Além disso, as novas gerações estão nascendo ou crescendo permeadas pelas novas tecnologias (os chamados nativos digitais), de forma que os alunos atuais - representantes dessas gerações - pensam e processam as informações de maneira distinta (PRENSKY, 2001).

Esses nativos digitais vivenciam situações cotidianas por meio das redes sociais, utilizam instrumentos tecnológicos diversificados e possuem maior relação de compreensão com as linguagens não verbais. Nesse sentido, não seria estranho que os discentes, representantes desse grupo, tenham dificuldade em assimilar conteúdos e informações da forma tradicional.

Nesse contexto, estabelecer relações entre a prática social efetiva e a prática pedagógica, exige, por parte do docente, incorporar e revisitar os multiletramentos:

Necessitamos, então, falar em letramentos, no plural mesmo, pois a multimodalidade é um traço constitutivo do discurso oral e escrito. Faz-se necessário ressaltar, também, a diversidade de arranjos não padrão que a escrita vem apresentando na mídia em função do desenvolvimento tecnológico. Em consequência, os nossos habituais modos de ler um texto estão sendo constantemente reelaborados (DIONÍSIO, 2011, p. 139).

Segundo Rojo (2012, p. 13), os multiletramentos apontam para dois tipos de multiplicidade: "a multiplicidade cultural das populações e a multiplicidade semiótica de constituição dos textos por meio dos quais ela se informa e se comunica".

Dentro desta última perspectiva, o trabalho com múltiplas linguagens torna-se de grande importância na prática docente, conforme destacam Nascimento, Bezerra \& Heberle (2011), uma vez que a própria materialização 
das interações sociais exige que suportes e linguagens diversas sejam ativadas, seja para sua leitura ou para sua produção, o que evidencia uma maior recorrência no uso de mídias, redes sociais e blogs nas atividades sociais e, consequentemente, docentes.

\section{Mídia podcast e o conceito de cibercultura}

Diante dessa configuração delineada pela pedagogia dos multiletramentos, há um conceito muito pertinente, quando se fala na apropriação de conhecimentos e domínio da tecnologia: o letramento digital.

Mais que conhecimento técnico, letrar-se digitalmente requer a competência de realizar, adequadamente, as práticas sociais que necessitam da utilização de recursos e ferramentas digitais e tecnológicas (RIBEIRO, 2009).

Nesse sentido, a escola também precisa apropriar-se das ferramentas, das linguagens multimodais e das novas formas de leitura e escrita para que seus alunos consigam exercer tais demandas sociais de forma competente.

Para tanto, entender o lugar-comum no qual as novas formas de leitura e escrita se enquadram, torna-se pertinente para a atuação docente. Assim, diante das transformações das práticas mencionadas, deve-se observar 0 ciberespaço e suas particularidades.

Segundo Levy (1999, p.142):

O ciberespaço suporta tecnologias intelectuais que amplificam,
exteriorizam e modificam numerosas funções cognitivas humanas:
memória (banco de dados, hiperdocumentos, arquivos digitais de
todos os tipos), imaginação (simulações), percepção (sensores
digitais, telepresença, realidades virtuais), raciocínios (inteligência
artificial, modelização de fenômenos complexos).

Ainda, segundo o autor, essas tecnologias favorecem novas formas de acesso às informações e novos estilos de raciocínio e de conhecimento. Isto é corroborado pela percepção que temos das novas gerações. Nascidos em meio à evolução quase imediata da tecnologia, esses sujeitos possuem capacidades cognitivas diferentes de outras gerações. Seus olhares, suas estratégias de 
leitura e busca de informações modificam, também, técnicas e processos relacionados às práticas em sala de aula.

O podcast, segundo Primo (2005, p.17), é um "processo mediático que emerge a partir da publicação de arquivos de áudio na internet". Diferentemente da rádio tradicional, o podcast possui maior acessibilidade na produção dos conteúdos (FREIRE, 2013).

Dentre suas principais características, a liberdade de expressão na produção dos podcasts torna-se singular. Por meio da fala, sua principal especificidade, o usuário/participante pode utilizar o recurso como veículo de músicas e playlists preferidas, embora também possam ser disseminados conteúdos diversos. Além disso, um benefício à utilização do podcast, seja como participante/produtor ou ouvinte, é a não obrigatoriedade da transmissão ao vivo, ou seja, o ouvinte pode acessar os conteúdos em momento posterior à publicação.

De acordo com Freire, a utilização da ferramenta é simples:

[...] basta ao produtor possuir um computador de capacidade média, fone de ouvido ou caixas de som no seu PC, um microfone (de preço bastante reduzido em modelos mais simples, girando em torno de $\mathrm{R} \$$ 10), um programa de gravação e edição de áudio, como o Audacity e uma conexão com a internet de velocidade média (FREIRE, 2010, p. 162-163).

Nesse sentido, esse recurso torna-se bastante valorativo ao pensar na prática em sala de aula. Mais especificamente na prática da oralidade em Língua Portuguesa - prática não muito difundida na escola - torna-se um eixo de ensino crucial para a prática em questão:

Desse modo, focando-se no que é feito pelo podcast - programas de locução, debate, exposição verbal, música e entre outros -, percebese que se trata, essencialmente, de reprodução de oralidade por um meio tecnológico, portanto, uma tecnologia de oralidade. A partir disso, cabe afirmar que podcast consiste em um modo de produção/disseminação livre de programas distribuídos sob demanda e focados na reprodução de oralidade e/ou de músicas/sons (FREIRE, 2013, p. 68).

Portanto, trata-se de uma mídia sonora/oral que permite sustentar a prática da oralidade de forma efetiva, ou seja, respeitando as práticas orais de 
forma natural e dinâmica, conforme os documentos oficiais e as teorias sobre ensino de Língua Materna.

\section{Linguagem/gênero de texto/sequência didática/capacidades de linguagem - em uma breve discussão}

Todo professor de línguas, implícita ou explicitamente, realiza seu trabalho em sala de aula a partir das concepções que possui acerca do que entende por língua, linguagem, ensino, aprendizagem, dentre tantos outros aspectos envolvidos no fazer docente. Assim, como a intenção deste artigo é apresentar uma proposta de trabalho que possa ser implementada em sala de aula, julgamos essencial explicitar, minimamente, quais concepções norteiam a proposta apresentada por nós.

Assumimos, neste trabalho, uma concepção que vê a língua(gem) como constitutiva do ser humano ao mesmo tempo em que se constitui por ele. Nessa perspectiva, defendemos que o ensino de línguas (materna ou estrangeira) deve priorizar o funcionamento da linguagem em suas práticas sociais, o que significa criar situações em sala de aula que se voltem ao trabalho com os mais diversos gêneros de texto, focalizando suas condições de produção, circulação e consumo, bem como a textualização.

Importa, neste momento, justificar nossa escolha pelo termo gênero "de texto". Baseando-nos na concepção sociointeracionista, entendemos texto como unidades comunicativas globais, cujas características composicionais dependem das propriedades das situações de interação e das atividades gerais que comentam, assim como das condições históricosociais de sua produção (BRONCKART, 2008, p. 113).

Dessa forma temos que, ao nos utilizarmos da língua(gem) (atividade linguageira), lançamos mão de enunciados (orais ou escritos) que representam e se configuram em um ou outro domínio da atividade humana, a que Bronckart denomina de atividade geral. Essa atividade geral nos leva a toda e qualquer espécie de texto, o qual se concretiza em um gênero. Essas noções 
apresentadas pelo ISD, a partir dos estudos de Bronckart, interligam-se com a teoria bakhtiniana/voloshinoviana quando afirma que "Todas as esferas da atividade humana, por mais variadas que sejam, estão sempre relacionadas com a utilização da língua" (BAKHTIN/VOLOSHINOV, 1997, p. 279), utilização que se efetua mediante enunciados orais e/ou escritos, a que o referido autor denomina gêneros do discurso, ou seja, tipos relativamente estáveis de enunciados, nos termos de Bakhtin/Voloshinov (1997).

Schneuwly (2010, p. 25) apresenta a terminologia "gênero" como

um megainstrumento, como uma configuração estabilizada de vários subsistemas semióticos (sobretudo linguísticos, mas também paralinguísticos), permitindo agir eficazmente numa classe bem definida de situações de comunicação.

Parece clara, portanto, a importância de se estabelecer um ensino de línguas com base em gêneros, pois reconhecemos que tal perspectiva pode contribuir para se atingir o que as Diretrizes Curriculares da Educação Básica do Estado do Paraná - Língua Portuguesa - DCE-LP ${ }^{4}$ apresentam como tarefa da escola:

[...] possibilitar que seus alunos participem de diferentes práticas sociais que utilizem a leitura, a escrita e a oralidade, com a finalidade de inseri-los nas diversas esferas de interação. Se a escola desconsiderar esse papel, o sujeito ficará à margem dos novos letramentos, não conseguindo se constituir no âmbito de uma sociedade letrada (PARANÁ, 2008, p. 48).

Entendemos que os referenciais trazidos pelos pesquisadores de Genebra podem se tornar um caminho teórico-metodológico que possibilite a transposição da teoria do ensino por meio de gêneros para a prática de sala de aula, justamente devido ao procedimento denominado SD, a qual é definida como "um conjunto de atividades escolares organizadas, de maneira sistemática, em torno de um gênero textual oral ou escrito" (DOLZ, NOVERRAZ e SCHNEUWLY, 2010, p. 82).

\footnotetext{
${ }^{4}$ Entregue em sua versão final no ano de 2008, as DCE constituem o conjunto de documentos que orienta as ações didático-pedagógicas dos Ensinos Fundamental II e Médio das escolas públicas do estado do Paraná, havendo um caderno específico para cada disciplina da matriz curricular.
} 
O procedimento SD apresenta uma estrutura de base, conforme definido pelo grupo de autores genebrinos, que se configura em etapas assim denominadas: a) apresentação da situação; b) produção inicial; c) módulos necessários, de acordo com as necessidades de aprendizagem de uma determinada turma de alunos e d) produção final.

Importa frisar que um ensino com base em gêneros, na perspectiva do ISD, não significa transformar as aulas de línguas em aulas que se voltem a ensinar o gênero, incorrendo no erro de gramaticalizá-los, pois "os gêneros não se ensinam, se aprendem, em processos de socialização" (MATÊNCIO, 2006b, p. 225 apud KLEIMAN, 2013, p. 55). Corroborando Matêncio, Machado (2005) assevera:

[...] a reflexão teórica que temos desenvolvido nos aponta que o que os autores do ISD consideram como 'ensinar gêneros', na verdade, não significa tomá-los como o objeto real de ensino e aprendizagem, mas como quadros da atividade social em que as ações de linguagem se realizam. $O$ objeto real de ensino e aprendizagem seriam as operações de linguagem necessárias para essas ações, operações essas que, dominadas, constituem as capacidades de linguagem (MACHADO, 2005, p. 258).

As capacidades de linguagem, organizadas em quatro tipos de operação - Capacidades de Ação, Capacidades Discursivas, Capacidades Linguísticodiscursivas e Capacidades de Significação ${ }^{5}$ - constituem-se em finalidades diferenciadas e que se complementam, conforme demonstrado na Figura 1:

Figura 1: Descrição das Capacidades de Linguagem

\footnotetext{
${ }^{5}$ As três primeiras capacidades de linguagem (ação, discursiva, linguístico-discursiva) são apresentadas pelo grupo de pesquisadores genebrinos. A capacidade de significação é proposta por Cristovão e Stutz (2011) e Cristovão (2013) como uma expansão ao referencial teórico de Genebra.
} 


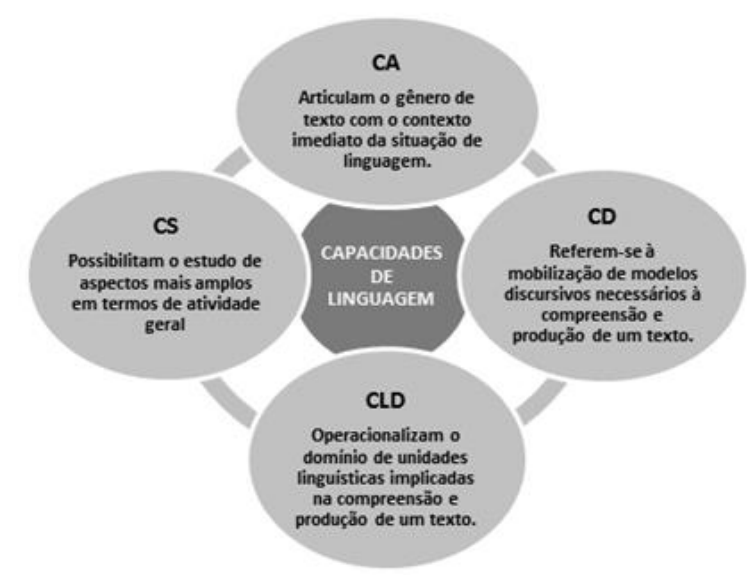

Fonte: Cristóvão et al. (no prelo), com base em Dolz e Schneuwly ([2004] 2010) e Cristovão e Stutz (2011).

Devido ao pouco espaço destinado a textos dessa natureza, não traremos maior detalhamento acerca das capacidades de linguagem, mas indicamos algumas possibilidades de leitura com o intuito de tratar com mais profundidade $o$ tema. ${ }^{6}$

\section{Práticas de oralidade, leitura e escrita entrelaçadas ao gênero poema e à mídia podcast}

De acordo com Cosson, o letramento literário não corresponde somente ao domínio da leitura de textos literários. Segundo o autor, esse é um letramento diferente dos demais, pois cabe à literatura "[...] tornar o mundo compreensível transformando a sua materialidade em palavras de cores, odores, sabores e formas intensamente humanas" (COSSON, 2006, p. 17). Ainda, de acordo com o autor, a escola assume papel primordial no que tange ao letramento literário visto que demanda um tratamento diferenciado com a linguagem, pois

[...] o objetivo maior do letramento literário escolar ou do ensino da literatura na escola é nos formar como leitores, não como qualquer

6 Trabalhos de pesquisa desenvolvidos por membros do Grupo de Pesquisa Linguagem e Educação - UEL, sob a coordenação da Professora Doutora Vera Lúcia Lopes Cristovão, podem ser acessados com o intuito de se obter um maior aprofundamento das questões referentes ao procedimento SD e capacidades de linguagem: Petreche (2008), Ferrarini (2009), BeatoCanato(2009), Lanferdini (2012), Stutz (2012), Pontara (2015), Lenharo (2015). 
leitor ou um leitor qualquer, mas um leitor capaz de se inserir em uma comunidade, manipular seus instrumentos culturais e construir com eles um sentido para si e para o mundo em que vive [...] (SOUSA e COSSON, 2011, p. 106).

Isso nos leva à escolha da mídia podcast, a qual é inserida na SD justamente para abrir um espaço diferenciado tanto para o trabalho com a oralidade quanto com os letramentos digital e literário. Sobre o fato de ser necessário que o texto literário ocupe espaços diferenciados, Sousa (2013, p. 175) afirma:

Para além do livro didático, o texto literário, se possível, precisa ocupar os mais diversos espaços da escola: murais, bibliotecas, exposições de texto e também os suportes advindos das novas tecnologias da informação: e-mail, blogs, facebook, entre outros.

Desta feita, trazemos em uma SD possibilidades de um trabalho que se volte para as práticas da leitura (quando são propostas atividades de leitura e compreensão de poemas); da escrita (ao apresentar à turma uma situação de comunicação que demandará atos de escrita de cada aluno) e da oralidade, ao propor que os poemas não sejam apenas lidos/compreendidos e produzidos, mas que também possam ser oralizados mediante as declamações que serão feitas via podcast com o intuito de criar espaços alternativos para que 0 letramento literário possa emergir em outros alunos e em toda e qualquer pessoa que possa vir a ter contato com tais podcasts.

Embora tenhamos clareza de que o poema não figure no agrupamento de gêneros apresentado por Dolz e Schneuwly (2010), entendemos ser de extrema necessidade promover reflexões acerca do trabalho que se pode realizar com e a partir do gênero poema. Para tanto, nos valemos de Vedovato (2008, p.83), ao afirmar que

[...] temos no poema características ainda não contempladas no agrupamento de gêneros, provisório, organizados por Dolz e Schneuwly (2004). Porém, podemos organizá-lo dentro da Ordem do Versejar, conforme proposto por Perfeito (2005) e um enquadramento na esfera literária. 
Apresentamos, com base em Perfeito e Vedovato (2011), os dados do quadro a seguir como sendo as principais características do gênero poema, em um modo mais amplo. 
Quadro1: Características do gênero poema

\begin{tabular}{|l|l|}
\hline \multirow{5}{*}{ Contexto de produção } & Produtor: é representado sempre pelo poeta. \\
\cline { 2 - 3 } & Destinatário: varia de acordo com os objetivos do autor. \\
\cline { 2 - 3 } & $\begin{array}{l}\text { Suporte: livros, jornais, internet, materiais didáticos } \\
\text { diversos, entre outros. }\end{array}$ \\
\cline { 2 - 3 } & $\begin{array}{l}\text { Contexto histórico e pessoal: normalmente influencia a } \\
\text { forma - a linguagem empregada, bem como no arranjo } \\
\text { do poema. }\end{array}$ \\
\hline A construção composicional & $\begin{array}{l}\text { Apresentação, organização em versos, estrofes, rimas ou } \\
\text { em versos brancos e/ou livres. Pode respeitar, em casos } \\
\text { específicos, a metrificação. o ritmo é marcado pela } \\
\text { relação do poeta com o seu contexto. Assim, pulsar } \\
\text { desenfreado no Modernismo ou pode se apresentar de } \\
\text { modo marcado como proposto pelos estudos literários } \\
\text { tradicionais. }\end{array}$ \\
\hline O conteúdo temático & Variável \\
\hline As marcas linguístico-enunciativas & $\begin{array}{l}\text { Figuras de linguagem e pensamento; forte presença de } \\
\text { estratos fonéticos/efeitos sonoros de linguagem, } \\
\text { preocupação com a construção visual. Possível emprego } \\
\text { de neologismos, de utilização de palavras-imagens e de } \\
\text { paralelismo sintático. }\end{array}$ \\
\hline
\end{tabular}

Fonte: Perfeito e Vedovato (2011, p. 251).

Assim, teríamos tais características como norteadoras gerais para elaboração das atividades de uma SD voltada para o gênero poema. Mas também seria necessário levar em consideração os subgêneros eleitos como enfoque desta SD - a quadra, a cinquina e o biopoema. De acordo com Schneuwly e Dolz (2010), antes de se elaborar uma SD, faz-se necessário passar pelo Modelo Didático $^{7}$ do(s) gênero(s) que será(ão) base para 0 material. Porém, por questões de limitação de espaço, não apresentaremos, neste trabalho, o Modelo Didático do gênero poema e dos subgêneros escolhidos. Limitamo-nos somente em apresentar uma definição de cada um deles:

\footnotetext{
${ }^{7}$ Schneuwly e Dolz (2010) esclarecem que esse processo envolve: I) conhecer o estado da arte sobre o gênero a ser didatizado, o que inclui também suas características linguísticodiscursivas; II) ter conhecimento das possíveis capacidades e dificuldades dos alunos a quem a SD se destina, além do que preconizam os documentos oficiais quanto às orientações de ensino-aprendizagem para a língua em questão - compondo o princípio da pertinência; III) possibilitar que os saberes didatizados estejam coerentes com os objetivos propostos.
} 
Quadro2: Os subgêneros quadra, cinquina, biopoema

\begin{tabular}{|c|c|}
\hline Quadra & $\begin{array}{l}\text { A forma fixa de poesia popularmente chamada de quadrinha ou trova } \\
\text { compõe-se de quatro versos (daí vem o nome). Com rima obrigatória } \\
\text { entre o segundo e o quarto verso. A medida mais comum de uma } \\
\text { quadrinha é o verso de sete silabas, redondilha maior, e sua riqueza } \\
\text { temática é notável. É a forma preferida da lírica popular e a mais } \\
\text { frequente no nosso folclore (RADICHI, 2013). }\end{array}$ \\
\hline Cinquina & 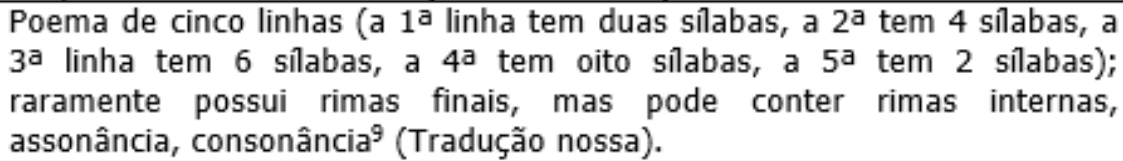 \\
\hline Biopoema & $\begin{array}{l}\text { Bio, nesse caso, não significa biologia - a ciência da vida; em vez disso, } \\
\text { bio indica biografia, escrevendo sobre a vida. Essas estruturas de } 10 \\
\text { linhas - o biopoema - começam com o primeiro nome da pessoa e } \\
\text { terminam com o sobrenome. As linhas } 2 \text { a } 9 \text { fornecem descritores sobre a } \\
\text { vida da pessoa }{ }^{10} \text {. (Tradução nossa). }\end{array}$ \\
\hline
\end{tabular}

Fonte: As autoras, com base nas referências indicadas.

Após essa breve explanação sobre os subgêneros do gênero poema e a mídia com os quais iremos trabalhar, passamos à descrição das atividades que compõem a SD.

\section{Descrição da Proposta de Atividades}

Para elaboração do material, optamos por trazer, em uma única SD, os três subgêneros por levar em consideração que: a) a quadra, devido à sua grande presença em atividades desenvolvidas no Ensino Fundamental I, pode vir a ser um aspecto facilitador e motivador para o trabalho com a expressão escrita que se pretende desenvolver; b) tanto a cinquina quanto o biopoema apresentam formas estruturais bem marcadas, mas, ao mesmo tempo, facilitadoras no que tange à organização das palavras de um modo poético; c) os três subgêneros podem, de forma simples, permitir que os alunos falem sobre si - intuito maior de nosso trabalho.

Apresentamos, a seguir, um quadro que sintetiza as atividades da SD, juntamente com os objetivos de cada seção. 
Quadro3: Organização geral da SD e seus objetivos

\begin{tabular}{|c|c|}
\hline \multicolumn{2}{|c|}{ SEQUENCIA DIDATICA: "POEMAS NA MIDIA PODCAST-PROMOVENDO REFLEXOES" } \\
\hline \multicolumn{2}{|l|}{$\begin{array}{l}\text { Ano: } 6^{\circ} \text { ano do Ensino Fundamental } \\
\text { Tempo de duração: } 13 \text { aulas }\end{array}$} \\
\hline Atividades propostas & Objetivos \\
\hline $\begin{array}{l}\text { Apresentando a situação de comunicação, } \\
\text { Módulo 1, Iniciando a sua produção escrita } \\
\text { Aulas } 1 \text { e } 2 \\
\text { - Análise e descrição oral de imagens e/ou poemas } \\
\text { envolvendo temas pessoais } \\
\text { - Apresentação da produção escrita e oral a ser } \\
\text { desenvolvida. } \\
\text { - Produção escrita inicial de um poema a partir da } \\
\text { situação de comunicação apresentada. }\end{array}$ & $\begin{array}{l}\text { - Situar o aluno no contexto do trabaho que será } \\
\text { desenvolvido; } \\
\text { - Apresentar, brevemente, os conteúdos que } \\
\text { serão enfocados; } \\
\text { - Discutir sobre o projeto de classe com os } \\
\text { alunos; } \\
\text { - Possibilitar que o aluno construa suas primeiras } \\
\text { reflexões acerca do gênero e do tema enfocados. }\end{array}$ \\
\hline $\begin{array}{l}\text { Módulo } 2 \\
\text { Aulas } 3,4,5 \\
\text { - Pesquisa no laboratório de informática e/ou nos } \\
\text { celulares dos alunos sobre os subgêneros cinquina, } \\
\text { biopoema quadra. } \\
\text { - Estudo sobre o contexto de produção dos poemas } \\
\text { selecionados. }\end{array}$ & $\begin{array}{l}\text { - Possibilitar que o aluno entre em contato com } \\
\text { textos do gênero enfocado; } \\
\text { - Situar o aluno a respeito da função social dos } \\
\text { textos em estudo; } \\
\text { - Propiciar reflexóes sobre contexto (de produção, } \\
\text { de circulação), sobre tema, conteúdo temático. } \\
\text { - Realizar inferências sobre: quem escreve o } \\
\text { texto, para quem ele é dirigido, sobre qual } \\
\text { assunto, quando o texto foi produzido, onde foi } \\
\text { produzido, para qual objetivo. }\end{array}$ \\
\hline $\begin{array}{l}\text { Módulo } 3 \\
\text { Aulas } 6 \text { e } 7 \\
\text { - Estudo sobre a organização de cinquinas, biopoemas } \\
\text { e quadras como: títulos, formato do texto, localização } \\
\text { de informação especófica no texto etc. }\end{array}$ & $\begin{array}{l}\text { - Possibilitar que o aluno realize a planificação } \\
\text { global do texto, refletindo sobre as principais } \\
\text { características relacionadas à organização do } \\
\text { conteúdo do/no texto. }\end{array}$ \\
\hline $\begin{array}{l}\text { Módulo } 4 \\
\text { Aula } 8 \\
\text { - Estudo da organização da linguagem nos poemas. }\end{array}$ & $\begin{array}{l}\text { - Possibilitar que o aluno opere e reflita sobre } \\
\text { elementos pertinentes às escolhas lexicais, rimas } \\
\text { etc. }\end{array}$ \\
\hline
\end{tabular}




\begin{tabular}{|c|c|}
\hline $\begin{array}{l}\text { Continuando com a produção escrita - revisão e } \\
\text { reescrita } \\
\text { Aulas } 9 \text { e 10: } \\
\text { - Retomada da produção escrita a partir dos critérios } \\
\text { da lista de constatação e dos apontamentos feitos } \\
\text { pelo professor nos textos produzidos pelos alunos. }\end{array}$ & $\begin{array}{l}\text { - Abrir espaço para que o aluno possa refletir } \\
\text { sobre seu texto, sobre o texto de colegas, a partir } \\
\text { dos estudos realizados, utilizando-se da lista de } \\
\text { constatação e observando as anotações do } \\
\text { professor, promovendo momentos de regulação, } \\
\text { por parte do aluno, sobre o seu próprio texto. }\end{array}$ \\
\hline $\begin{array}{l}\text { Módulo } 5 \\
\text { Aula } 11 \text { e } 12 \\
\text { - Compreensão dos elementos que cooperam na } \\
\text { construção de quadras, biopoemas, cinquinas. } \\
\text { - Estudo das escolhas lexicais na produção de } \\
\text { quadras, biopoemas, cinquinas. }\end{array}$ & $\begin{array}{l}\text { - Possibilitar que o aluno opere e reflita sobre } \\
\text { elementos pertinentes às escolhas lexicais, coesão } \\
\text { verbal, nominal, escolhas lexicais, classes de } \\
\text { palavras, figuras de linguagem etc. }\end{array}$ \\
\hline $\begin{array}{l}\text { Produção final e Poemas em podcasts } \\
\text { Aula } 13 \\
\text { - Reescrita final do poema. } \\
\text { - Criação do podcast. } \\
\text { - Criação do blog (etapa produzida pelo professor). } \\
\text { - Publicação do podcast produzido, no blog, com a } \\
\text { finalidade de divulgar os trabalhos dos alunos durante } \\
\text { o ano letivo. }\end{array}$ & $\begin{array}{l}\text { - Realizar a escrita final do texto, a partir da lista } \\
\text { de constatação e das observações do professor. } \\
\text { - Possibilitar espaços para que os alunos oralizem } \\
\text { seus poemas, refletindo sobre elementos como: } \\
\text { pronúncia, entonação etc. } \\
\text { - Possibilitar que os alunos se engajem em } \\
\text { atividades de linguagem como prática social. } \\
\text { - Permitir que os alunos reflitam sobre o uso das } \\
\text { mídias sociais por meio do podcast e de suas } \\
\text { publicações. }\end{array}$ \\
\hline
\end{tabular}

Fonte: As autoras.

Apresentamos, a seguir, a SD elaborada a partir dos referenciais teóricometodológicos já discutidos. 


\section{Poemas na Mídia Podcast: Promovendo Reflexões}

\#presentando a situação de comunicação

1. Faça a leitura da imagem e das informações do quadro abaixo. Em seguida, converse com seu professor e seus colegas sobre as possiviveis relações entre a imagem apresentada e as informações do quadro.

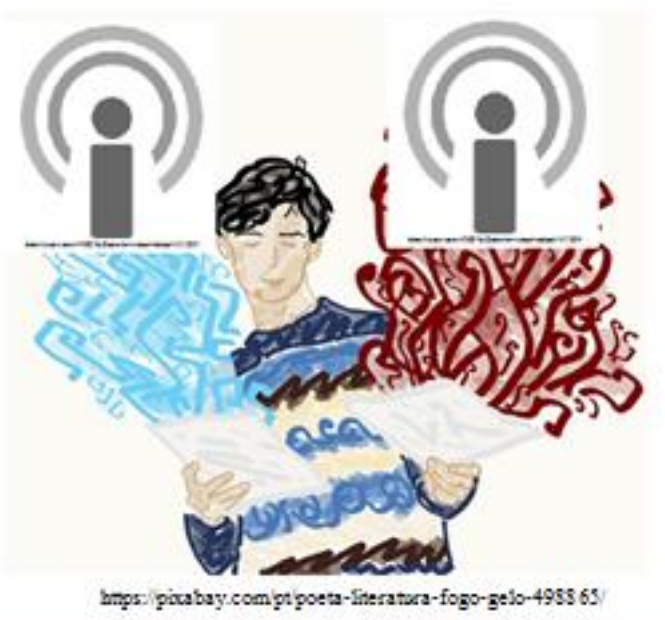

Nesta unida de você entrará em contato com poemas e com a midia podcast. Esse gênero de texto foi escolhido porque os poemas podem envolvê-lo em um trabalho diferenciado com a linguagem.

Por outro lado, a mídia podcast foi inserida neste estudo sobre poemas para que você possa, por meio da tecnologia, abrir espaços mais amplos de compartilhamento e troca de ideias.

$O$ estudo da unidade, portanto, permitirá a você:

- ler, compreender e produzir poemas;

- abordar e discutir questões envolvendo temáticas pessoais;

- reconhecer as especificidades das quadras, das cinquinas e dos biopoemas;

- reconhecer e compreender o que é um podcast;

- produzir um podcast a partir da declamacão do seu poema para ser disponibilizado na intemet.

Fontes: <https://pixabay.com/pt/poeta-literatura-fogo-gelo-498865/

https://pixabay.com/pt/\%C3\%ADcone-de-podcast-podcast-1322239/>. Acesso em: 10 jan. 2017.

\section{Módulo 1}

Gontextuafizando...

\section{Assista aos vídeos apresentados a seguir:}




\section{Vídeo I: \\ Quem eu sou (Sandy)}

Disponivel em:

$\angle$ https://www.youtube.com/watch? $\mathrm{v}=\mathrm{ohS}$

88T7itWw > Acesso em 10 ian. 2017

\section{Vídeo II:}

Quem sou eu? (Pedro Bandeira)

Disponivel em:

Shtps://www.youtube.com/watch?v=pA

dAaawNX U > Acesso em 10 ian.. 2017

\section{Resolva as atividades abaixo com base nos vídeos que você acabou de assistir.}

a) Há uma temática que se assemelha nos dois vídeos. Sobre o que eles tratam?

b) Observe os dois excertos abaixo e, com base em marcas linguísticas, responda quem está falando em cada um deles, ou seja, quem é o eu-lírico. Anote quais palavras lhe ajudaram a chegar à resposta dada.

\section{QUEM EU SOU (SANDY) \\ [...]Procurando \\ Nos meus sonhos \\ Descobrindo quem realmente eu sou \\ Inventando \\ Um caminho \\ Libertando quem realmente eu sou[...]}

\section{QUEM SOU EU? (PEDRO}

BANDEIRA)

[...]Eu queria que comigo

Fosse tudo diferente.

Se alguém pensasse em $\mathrm{mim}$,

Soubesse que eu sou gente.

c) Você considera que seja fácil, para um escritor, escrever algo sobre si mesmo? Por quê?

d) E se fosse para você ser um escritor que tivesse que escrever algo sobre si mesmo, sobre o que escreveria? Enumere as opções que mais lhe agradam, sendo ( 1 ) para o que mais the agrada e ( 5 ) para aquela que menos the agrada.

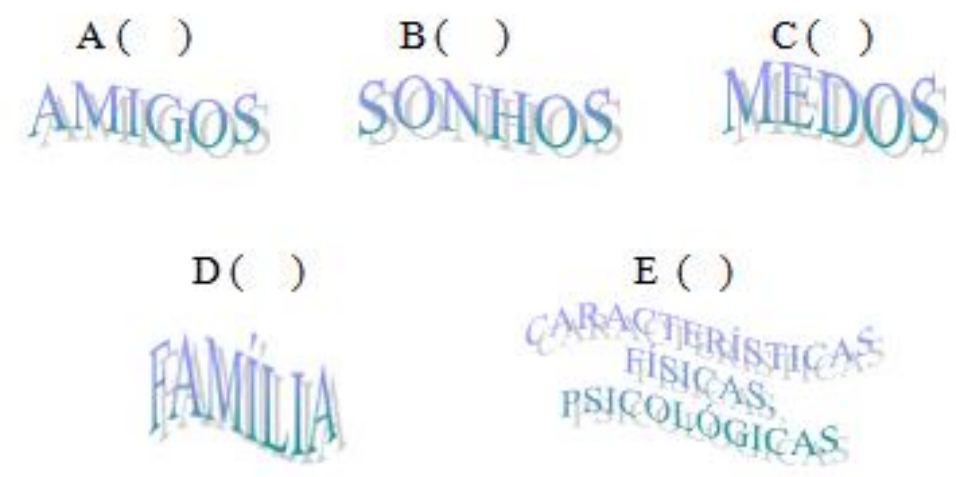




\section{3) Você conhece as músicas do Gabriel Pensador? Em uma de suas letras ele diz que:}

[...]

Eu gosto de escrever, eu gosto de escrever, crer ver

Ver crer, eu gosto de escrever e escrevo até poema

$[\ldots]$

(Gabriel Pensador, Linhas Tortas)

a) E você, gosta de ler/escrever poemas? Lembra-se de algum poema que leu ou escreveu? Do que você mais gosta nos poemas? Participe dessa discussão com seus colegas e professor. Depois, relate em seu caderno como é o gosto de sua classe quanto aos poemas.

b) Em sua opinião, os poemas são importantes para o ser humano? Por quê?

\section{4) Leia, a seguir, o que a escritora Ana Luisa Ribeiro comentou sobre a poesia:}

[...] "Se me perguntassem a função das tesouras, não gastaria muitas linhas pra dizer que servem para cortar. Assim como calculadoras servem para fazer contas complexas e trincos servem para trancafiar. Mas a poesia me parece livre de funções preestabelecidas. Quando me perguntam a função da poesia, penso imediatamente nos sentidos. Quando leio um poema, geralmente o faço após uma busca. Os poemas não me aterrorizam em pesadelos e nem se impõem em outdoors [em geral, não]. Também não os encontro com facilidade em jornais diários [desse jornalismo barato e descartável] e nem me aparecem na televisão a torto e a direito. Quando leio um poema, fiz certo esforço para tê-lo em mãos: num livro, num fanzine, num programa especial. Saí de casa para ouvir falar dele, entrei numa livraria e me dirigi à estante onde eles estão acumulados e empoeirados. Então a poesia me parece ter a função de ser algo diferente do ordinário, do comum, do mediano em meu dia-a-dia. [...] A poesia não serviria para explicar, explanar, comprovar, mas para parecer, fotografar, incidir". [...]

Fonte: \&http://www.revistazunai.com/depoimentos_debates/funcao_da_poesia.htm>Acesso em 16 jan., 2017.

a) Transcreva a parte que mais Ihe chamou a atenção na declaração da escritora. Justifique sua escolha.

b) Ouça, agora, a música "Linhas Tortas", de Gabriel Pensador, disponível em <https://www.youtube.com/watch?v=24QmQfPCsgQ> (Acesso em: 16 jan. 
2017). Depois, escreva em algumas linhas, se os dois autores (Gabriel Pensador e Ana Luisa Ribeiro) possuem ideias semelhantes ou não acerca do ato de ler/escrever poemas.

\section{5) Lançando o desafio...}

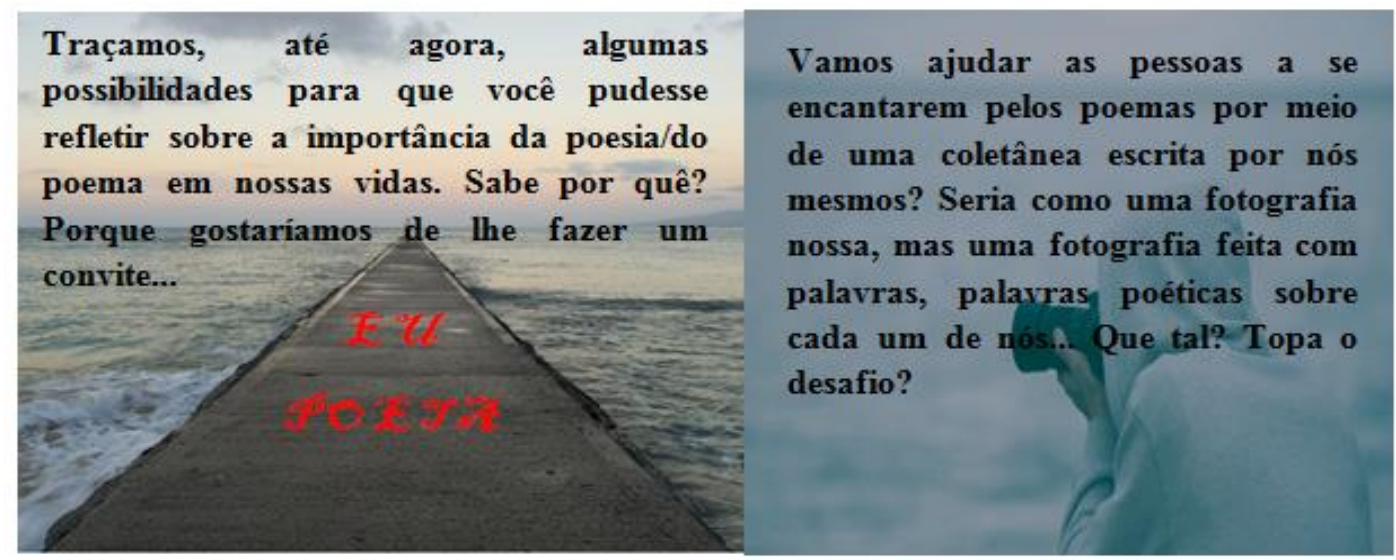

Fonte: <http://www.freeimages.co.uk/galleries/sports/relaxation/slides/contemplation.htm>. Acesso em: 10 jan. 2017.

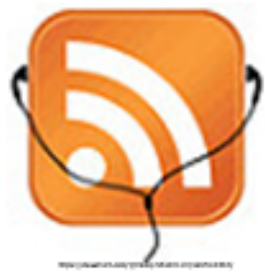

E para completar esse desafio, vamos torná-lo ainda maior! Não vamos escrever para nós mesmos. Vamos escrever para que outras pessoas possam nos ouvir, sim, nos ouvir... Que acha de transformarmos nossos poemas em textos orais em formato de podcasts?

Assim, o mundo todo poderá nos ouvir e saber quem nós somos, o que sentimos, do que gostamos ou não gostamos, enfim... muitos saberão que você, eu existimos e fazemos poesia! Mas esse é um outro assunto, sobre o qual trataremos mais à frente, ok?

Iniciando a sua produção escrita...

Peça a seu professor que o leve a um lugar diferente da sala de aula. Pode ser uma praça próxima da escola, um parque, ou até mesmo o pátio da escola, a biblioteca... Se quiser, e seu professor permitir, coloque um fone de ouvido e ouça uma música que te inspire nesse momento. Sim! Porque neste momento você vai iniciar seu processo de escrita. Isso mesmo! Escrever é um 
processo em que as palavras vão ganhando vida, vão se juntando de um modo tão especial até que consigam demonstrar todo o nosso sentimento, toda a nossa capacidade poética! ${ }^{8}$

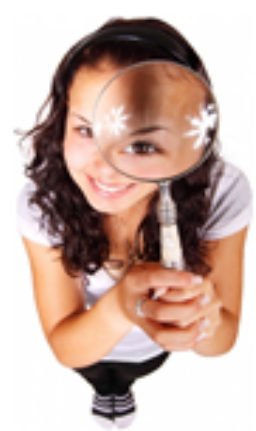

Seja agora o/a poeta e coloque seu poema no papel. O tema? Você já o escolheu no exercício número 3. Mas, se quiser, poderá trocar por outro que esteja marcado naquela atividade. Olhe para dentro de você e... mãos à obra!

Assim que terminar, entregue seu texto a seu professor. E lembre-se: esse é apenas seu primeiro encontro com seu texto. Você vai se reencontrar com ele em breve!

Fonte: <http://all-free-download.com/free-photos/download/woman-with-magnifyingglass_186653.html>. Acesso em: 10 jan. 2017.

\section{Módulo 2}

Gonfecendo mefhor ospoemas...

\section{1) Pesquisa:}

Cada aluno realizará uma pesquisa para que possa trazer poemas para a sala de aula. Você poderá:

a) pesquisar no laboratório de informática;

b) conversar com algum professor ou funcionário da escola e anotar o poema que ele Ihe indicar; Ihe indicar.

c) conversar com algum familiar/vizinho/amigo e anotar o poema que ele

Após ter o seu poema escrito em uma folha de sulfite, traga-o para a sala de aula, no dia marcado pelo professor. Cada aluno irá apresentar o poema escolhido, podendo ser feita uma leitura, uma declamação, uma encenação, uma apresentação do poema em PowerPoint. Em seguida, você e seus colegas confeccionarão o Mural Poético, onde todos os poemas ficarão expostos. Ah! Não se esqueça de mencionar a fonte de onde retirou o poema, bem como o nome do autor.

\section{2) Com base nos poemas do Mural Poético, responda:}

\footnotetext{
${ }^{8}$ Importante termos em mente que essa será a produção inicial dos alunos. Portanto, não será utilizada como instrumento avaliativo somativo, mas sim, será uma forma de avaliação diagnóstica para que o professor possa promover as alterações nos módulos da SD, para que atenda às necessidades da turma.
} 
a) O que há nesses textos que os diferencia de uma notícia de jornal, de um artigo de opinião, de uma receita, por exemplo?

b) Todos os poemas do Mural apresentam o mesmo formato? O que há de diferente entre eles?

c) E quanto ao tema? Há temas repetidos? Qual tema é mais interessante, em sua opinião? Por quê?

3) Vamos agora estudar um poema em especial: "Quem sou eu?" do autor Pedro Bandeira. Você já leu uma estrofe desse poema e já ouviu sua declamação no início dessa unidade. Mas agora vamos estudar um pouco mais sobre ele. Faça a leitura do poema associando-o com a imagem e depois resolva o que se propõe.

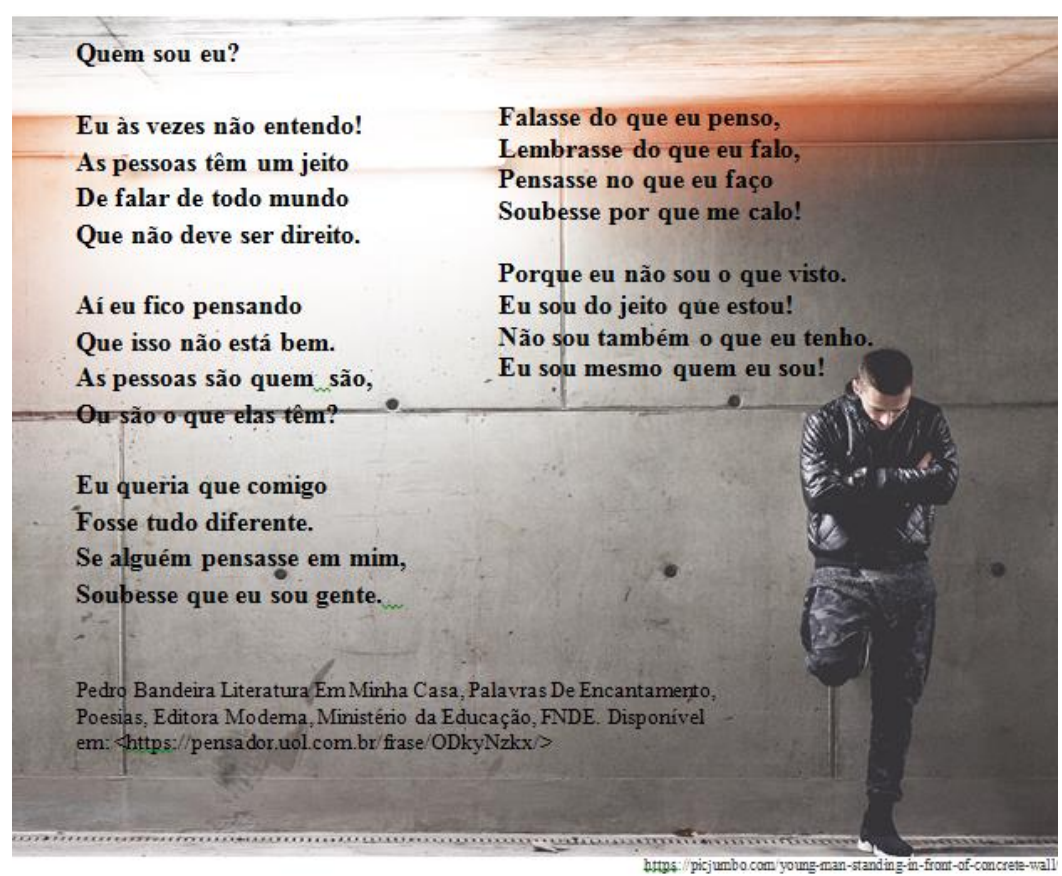

Fonte: <https://picjumbo.com/young-man-standing-in-front-of-concrete-wall/>. Acesso em: 10 jan. 2017.

a) O autor Pedro Bandeira escreveu, de uma forma poética, sobre um tema que tem sido discutido por muitos filósofos, escritores, além de outros poetas também. Qual tema é abordado no poema?

b) Tratando agora da imagem, em que sentido(s) ela se relaciona com o conteúdo do poema? 
c) E se fosse para você responder, em apenas uma linha, a pergunta feita por Pedro Bandeira. Que resposta você daria? Escreva-a no espaço abaixo.

d) Com o intuito de complementar sua resposta, faça uma busca (em revistas, internet ou um desenho de sua autoria) por imagem(ns) que venha(m) acrescentar mais significações à sua resposta. Cole essa(s) imagem(ns) em uma folha de sulfite, escreva sua frase e entregue a seu professor. Mas não coloque seu nome.

e) Montando um mural com o título "Quem somos nós?", você e seus colegas ajudarão seu professor a criar um belo mural para que as atividades do exercício "d" sejam afixadas. Em seguida, a tarefa de cada um será tentar descobrir quem é o autor de cada frase e, assim, descobrirão se conhecem bem uns aos outros.

f) E se perguntássemos quem é Pedro Bandeira? O que você poderia responder sobre o autor? Para ajudá-lo nessa tarefa, assista ao vídeo "Quem sou eu", disponível em: <https://www.youtube.com/watch?v=bfSLkYG0_bo> (Acesso em: 20 jan. 2017).

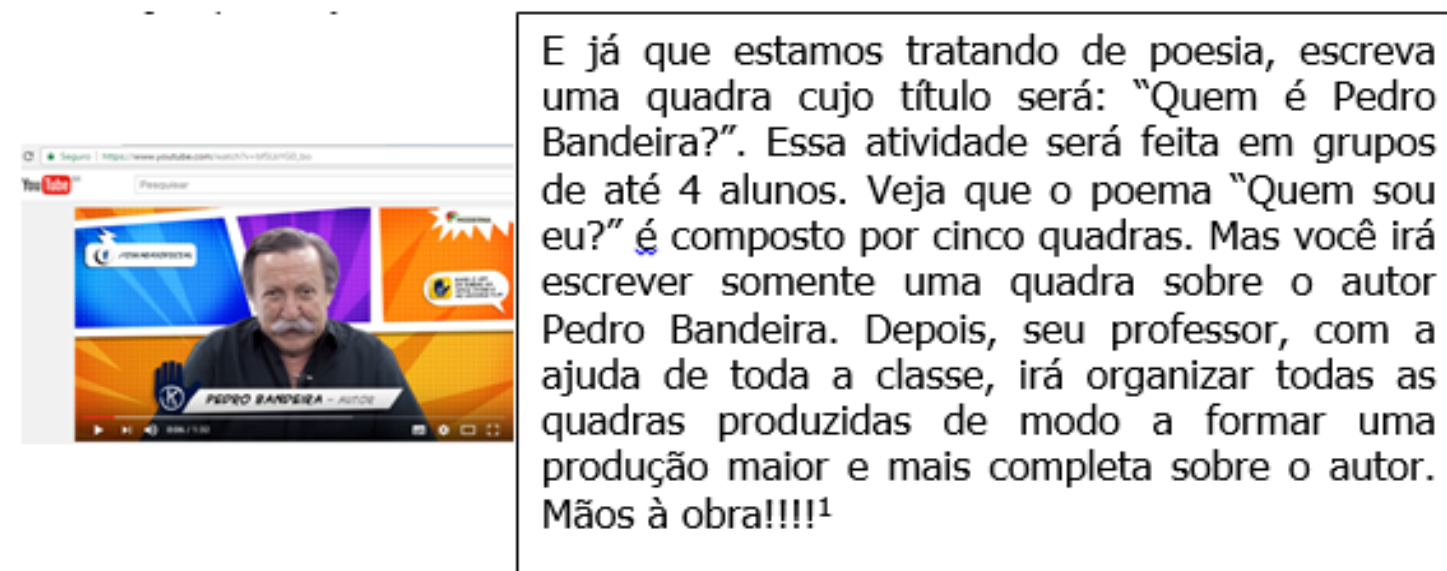

4) Já que estamos conversando sobre poetas, sobre escritores, leia abaixo um poema denominado de "biopoema" sobre um grande escritor inglês. Como o texto está em língua inglesa, segue ao lado a tradução. Mas você pode pedir ao professor de inglês que leia o texto com você. Depois de uma leitura atenta, responda às questões que seguem. 


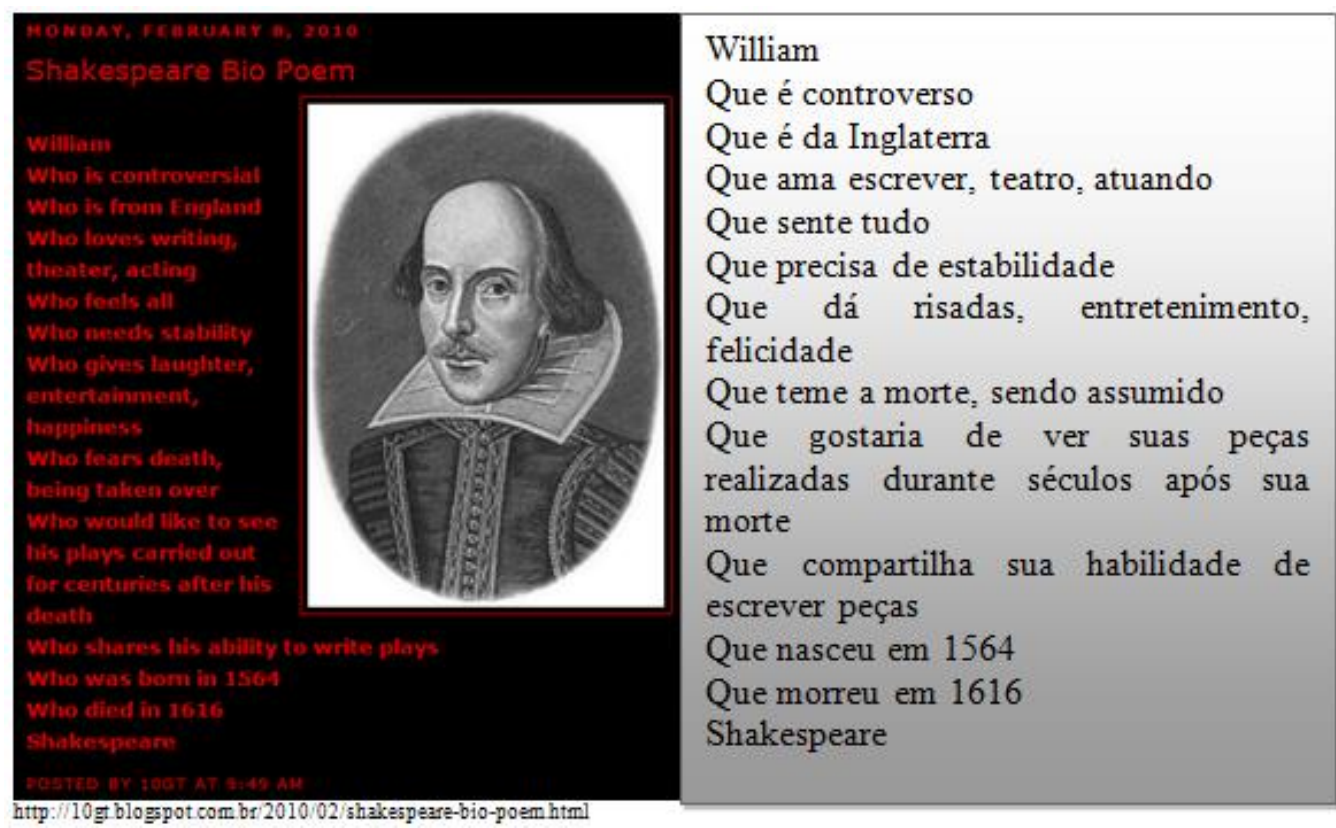

Fonte do poema em inglês: <http://10gt.blogspot.com.br/2010/02/shakespeare-biopoem.html>. Acesso em: 10 jan. 2017.

a) Qual seria a finalidade desse poema? Quem poderia tê-lo escrito?

b) A quem se destinaria um poema como esse e onde ele poderia ser encontrado?

c) Comparando o poema sobre Shakespeare e o poema de Pedro Bandeira, em que eles se assemelham e/ou se diferenciam:

I- quanto ao tema:

II - quanto à forma:

d) Você percebeu que o título do poema apresenta a palavra "Bio". Relacionando o título com o poema em si, essa palavra significa:

I ( ) biologia II ( ) biografia III ( ) biodiversidade

e) Justifique sua resposta anterior.

\section{5) 0 texto abaixo também fala sobre Willian Shakespeare. Leia-o e depois responda ao que se pede.}


Shakespeare é considerado um dos mais importantes dramaturgos e escritores de todos os tempos. Seus textos literários são verdadeiras obras de arte e permaneceram vivas até os dias de hoje, sendo retratadas frequentemente pelo teatro, televisão, cinema e literatura.

Nasceu em 23 de abril de 1564, na pequena cidade inglesa de StratfordAvon. Nesta região começa seus estudos e já demonstra grande interesse pela literatura e pela escrita. Com 18 anos de idade casou-se com Anne Hathaway e, com ela, teve três filhos. No ano de 1591 foi morar na cidade de Londres, em busca de oportunidades na área cultural. Começa a escrever sua primeira peça, Comédia dos Erros, no ano de 1590, e termina quatro anos depois. Nesta época escreveu aproximadamente 150 sonetos.

No ano de 1610, retornou para Stratford, sua cidade natal, local onde escreveu sua última peça, A Tempestade, terminada somente em 1613. Em 23 de abril de 1616 faleceu o maior dramaturgo de todos os tempos, de causa ainda não identificada pelos historiadores.

Os textos de Shakespeare fizeram e ainda fazem sucesso, pois tratam de temas próprios dos seres humanos, independente do tempo histórico. Amor, relacionamentos afetivos, sentimentos, questões sociais, temas políticos e outros assuntos, relacionados à condição humana, são constantes nas obras deste escritor.

Fonte: Adaptado de <https/www.suapesquisa.com/shakespeare/> Acesso em 20 jan, 2017.

a) Explique as diferenças entre os dois textos que falam sobre Shakespeare, observando:

I- a forma em que foram escritos:

II - o conteúdo presente em cada um deles:

b) Qual seria a função de cada um desses textos? Você acredita que, por se tratarem do mesmo tema, os dois textos têm o mesmo objetivo ou não? Justifique sua resposta.

c) Qual dos dois textos sobre Shakespeare chamou mais a sua atenção? Por quê?

6) Vamos tratar agora de um outro tema que também foi apresentado no Módulo 1: amizade/amigos. A seguir, você encontrará três textos bem interessantes. 
TEXTO 1: Podcast. Amigos são peças fundamentais em nossas vidas.

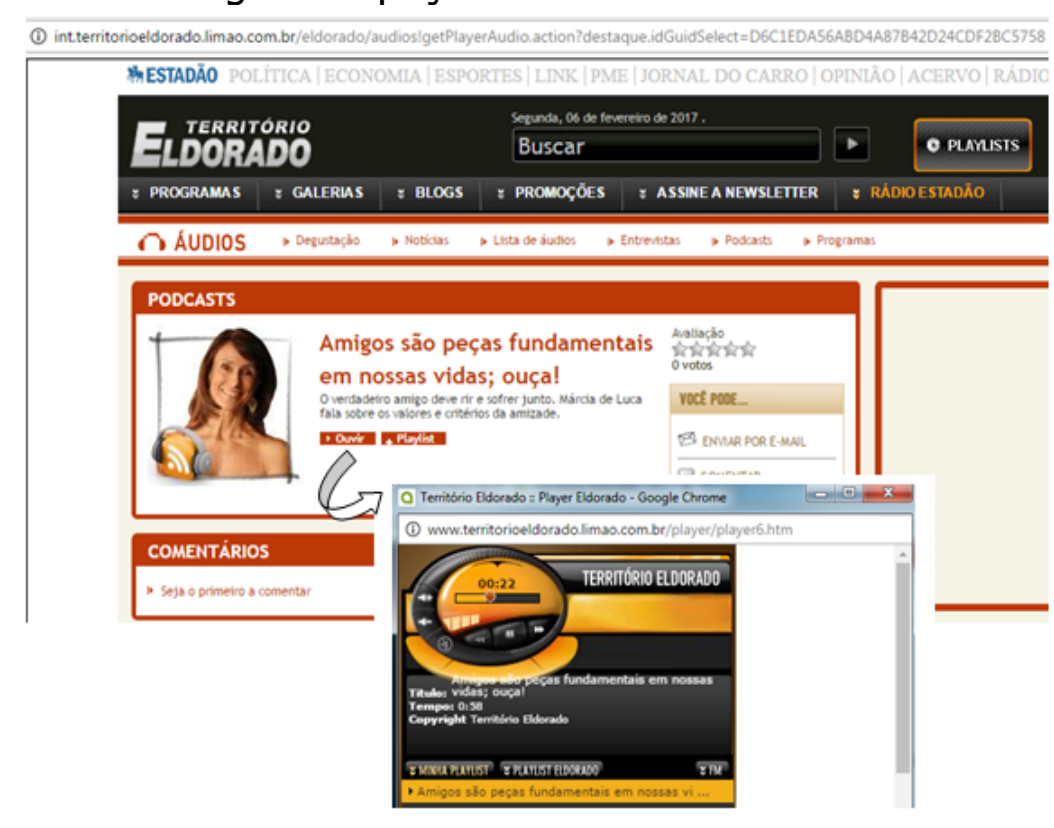

Fonte:

<http://int.territorioeldorado.limao.com.br/eldorado/audios!getPlayerAudio.action?destaque.idG uidSelect=D6C1EDA56ABD4A87B42D24CDF2BC5758> . Acesso em: 21 jan. 2017.

Para ouvir o texto, você poderá acessá-lo no laboratório de informática de sua escola ou até mesmo em seu celular. O endereço é:

<http://int.territorioeldorado.limao.com.br/eldorado/audios!getPlayerAudio.acti on?destaque.idGuidSelect=D6C1EDA56ABD4A87B42D24CDF2BC5758>. Acesso em: 21 jan. 2017 
TEXTO 2: O que é amigo.

- Seguro | https//www.significados.com.br/amigo/

Significados

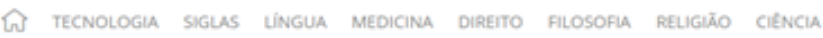

Significados , Geral , Amigo

Significado de Amigo

f. Compartilhar

O que é Amigo:

Amigo é o nome que se dá a um indivíduo que mantém um relacionamento de afeto, consideração e respeito por outra pessoa. $\mathrm{O}$ amigo é aquele que possui uma grande afeição por uma ou mais pessoas, que é leal, que protege e faz o possível para ajudar sempre.

Para denominar uma pessoa de amigo, não necessariamente os indivíduos precisam se conhecer há muito tempo, muitas amizades começam repentinamente e ganham importância por diversos motivos. Amigo é aquela pessoa que se confia acima de qualquer coisa, que está sempre disposto a ajudar, seja em situações boas ou ruins.

Para chamar alguém de amigo, nãonecessariamente precisa ser apenas amigo. Existem muitos familiares, como primos, tios, namorados e até mesmo os próprios pais do indivíduo podem ser considerados um amigo, por sua postura e jeito de agir, por ser alguém sempre disposto a conversar e ajudar.

Em alguns momentos, o amigo não precisa ter necessariamente os mesmos gostos e vontades, e em certos casos é esse exatamente o fato que os une. $\mathrm{O}$ amigo não precisa ser alguém completamente idêntico. $\hat{\mathrm{E}}$ aquele que tem o poder de acrescentar ao outro, com suas ideias, momentos de vida, informações etc., ou apenas alguém para dividir momentos e sentimentos.

Fonte: $\backslash$ https://www.significados.com.br/amig/> Acesso em 21 jan., 2017

TEXTO 3: (Atenção! Esse texto está em língua inglesa. Mas nós fizemos a tradução da parte que você precisará ler para realizar essa atividade. Seria importante você pedir a seu professor de inglês que ajudasse a compreender todo o restante).

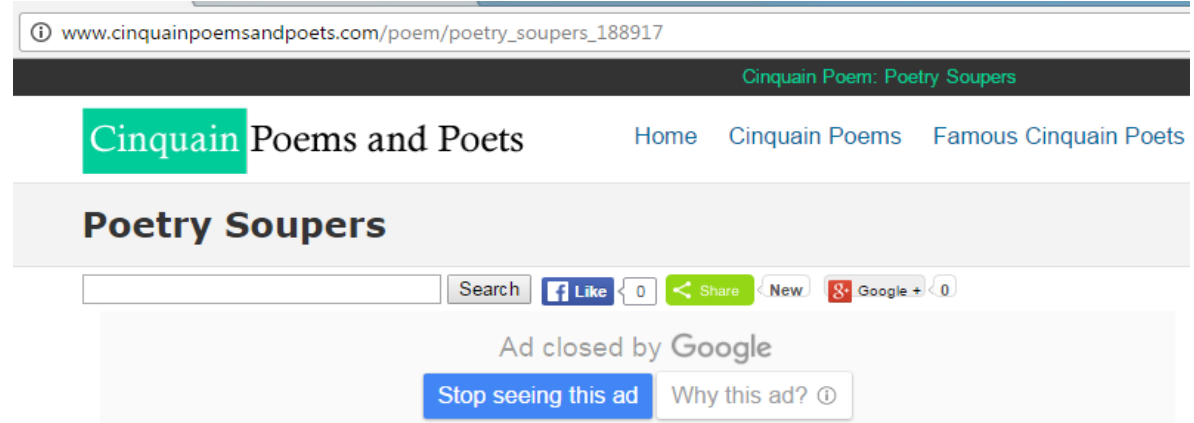

Home Cinquain Poems $»$ Poem

Friends

Diverse precious

Helping incouraging inspiring

Knowledge humor insight guidance

Poetry Soupers
Amigos

Diversos, preciosos

Ajudando, incentivando, inspirando

Guia de conhecimento, humor e ideias

Melhores da poesia

Fonte:<http://www.cinquainpoemsandpoets.com/poem/poetry_soupers_188917>. Acesso em: 21 jan. 2017. 
a) Os três textos apresentados circulam na internet. Contudo, cada um deles apresenta características próprias, apesar de falarem sobre o mesmo assunto. Sabendo disso, responda:

I- Quem seria o possível leitor de cada um dos textos?

II - A linguagem foi empregada em cada texto de um modo diferente, a fim de atingir seu objetivo. Qual o objetivo de cada um desses textos?

III - Em função desses objetivos, o que você percebeu de diferente quanto ao uso da linguagem em cada um dos textos?

\section{Módulo 3}

Gonfiecendo a organização dos poemas...

1) Nas atividades anteriores você entrou em contato com alguns poemas. Vamos saber um pouco mais sobre esse gênero de texto. Mas, primeiro, explique o que você entende por "poema" e "poesia".

\section{2) Agora, complete os espaços em branco na imagem abaixo, empregando as palavras "poesia" ou "poema".}

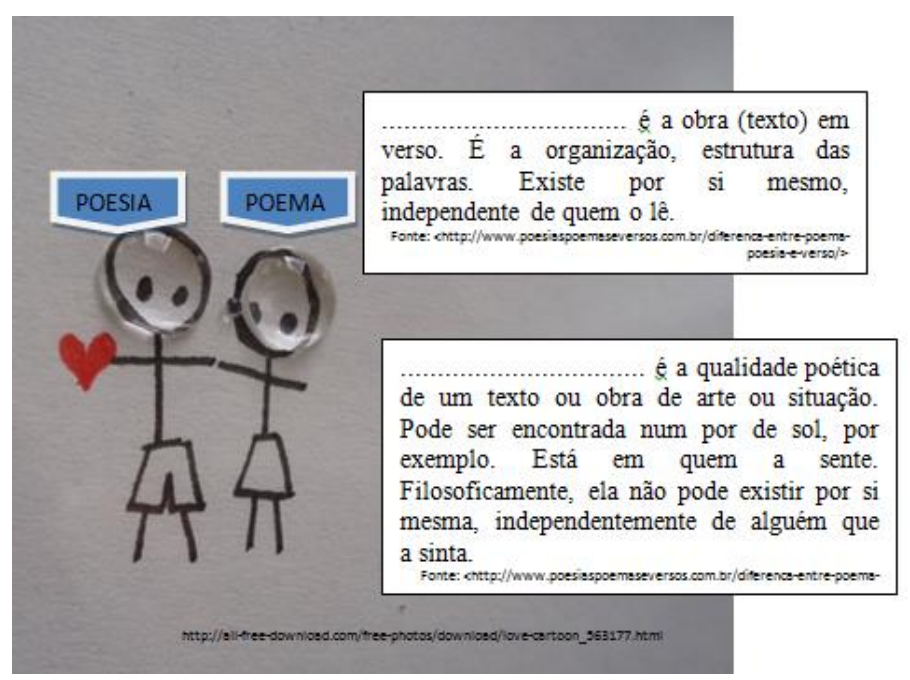

Fonte: <http://all-free-download.com/free-photos/download/love-cartoon_563177.html>. Acesso em: 10 jan. 2017. 
3) Agora, vamos tratar dos poemas que já lemos nos módulos anteriores. Volte aos Módulos 1 e 2 e releia os poemas com os quais já trabalhamos. Depois, numere as colunas abaixo de modo que cada definição esteja relacionada ao gênero correspondente.

\begin{tabular}{|c|c|}
\hline $\begin{array}{l}\text { ( 1) Estrofe de quatro versos. Iniciou-se com o cordel, mas hoje não é mais } \\
\text { utilizada pelos cordelistas. Porém as estrofes de quatro versos ainda são muito } \\
\text { utilizadas em outros estilos de poesia sertaneja, como a matuta, a caipira, a } \\
\text { embolada, entre outros. A mais usada é a que possui sete silabas. } \\
\text { Obrigatoriamente tem que haver rima em dois versos (linhas). Cada poeta tem } \\
\text { seu estilo. Uns usam rimar o segundo verso com o quarto. Outros preferem } \\
\text { rimar todas as linhas, alternando ou saltando. Pode ser a primeira com a } \\
\text { terceira e a segunda com a quarta. } \\
\text { Fonte: <http://cordelistaaurineide.blogspot.com.br/p/engracados.html }>\text { Acesso em } 25 \text { jan., } 2017 \text {. }\end{array}$ & ( )Biopoem \\
\hline $\begin{array}{l}\text { ( } 2 \text { ) "Quem sou eu?" é uma questão na mente de muitas pessoas. Quando } \\
\text { esses poemas são compartilhados, eles podem ajudar a construir } \\
\text { relacionamentos entre pares e promover uma comunidade coesa. Eles vão } \\
\text { além de aspectos de identidade que são frequentemente mais óbvios e } \\
\text { familiares (como etnia, gênero e idade), enfocando outros fatores que moldam } \\
\text { nossas identidades, como experiências, relacionamentos, esperanças e } \\
\text { interesses. Também podem ser uma maneira de demonstrar o que sabemos } \\
\text { sobre figuras históricas ou literárias. Fornecem uma estrutura para uma } \\
\text { pessoa pensar mais criticamente sobre as características de um indivíduo, } \\
\text { experiências e caráter. } \\
\text { Fonte: <https://www.facinghistory.org/resource-library/teaching-strategies/biopoem-identity- } \\
\text { poetry> Acesso em } 25 \text { jan., } 2017 \text {. }\end{array}$ & ( )Quadra \\
\hline $\begin{array}{l}\text { ( } 3 \text { ) É uma forma de poesia muito popular por causa de sua simplicidade. Foi } \\
\text { criada pela poeta americana Adelaide Crapsey cerca de } 100 \text { anos atrás, e é } \\
\text { semelhante às formas poéticas japonesas, como haikai e tanka. Possui apenas } \\
\text { cinco linhas, com apenas algumas palavras em cada linha, tornando-os fáceis } \\
\text { de escrever. Embora tenham apenas cinco linhas, os melhores poemas } \\
\text { conseguem contar uma pequena história. Em vez de apenas ter palavras } \\
\text { descritivas, eles também podem ter uma ação (algo acontecendo), um } \\
\text { sentimento causado pela ação, e uma conclusão ou término. } \\
\text { Fonte: <http://blogs.ksbe.edu/shdesa/2013/04/15/poetry-activity-nlw/> Acesso em } 25 \text { jan., } 2017 .\end{array}$ & ( )Cinquina \\
\hline
\end{tabular}

\section{4) Escolha uma quadra do poema "Quem sou eu?", já lido por você no módulo 1, copie-a em seu caderno. Em seguida, circule as rimas e escreva em quais versos elas aparecem.}

\section{5) Retome o poema produzido por você e seu grupo sobre o poeta Pedro Bandeira e responda:}

I - o poema produzido por vocês é uma quadra? Justifique sua resposta.

II - Há palavras que rimam? Se sim, em quais versos elas se encontram?

III- É necessário fazer alguma modificação em seu poema para que ele fique adequado às características de uma quadra? Se sim, este será o momento para reescrevê-lo. Caso esteja tudo adequado, ajude seu professor a montar o poema unindo todas as quadras produzidas. 
6) O poema a seguir foi escrito por Fernando Pessoa, um poeta português. Ele foi retirado de um audioblog intitulado "Estúdio Raposa", criado pelo português Luís Gaspar. Faça a leitura silenciosamente e depois resolva as atividades.

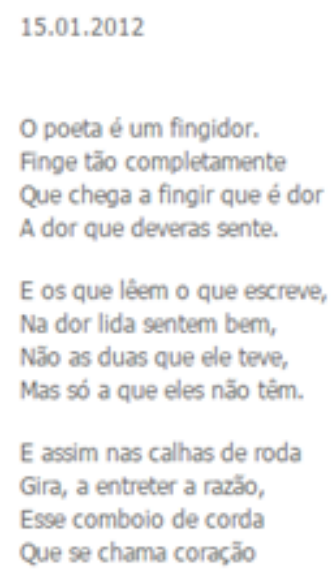

Sobre o Estúdio Raposa

Aqui, neste espaço, arrancam-se as palavras do papel e dizem-se, soprandothes vida, fazendo-as flutuar em sonoras centelhas de luz. Recitar realiza, quebrando o silêncio, aquilo que o silêncio pretende e não consegue.

\section{0000}

Podcast (estudio-raposa-audiocast): Download

\section{f}

(Fonte: <http://www.estudioraposa.com/> Acesso em: 25 jan., 2017.)

a) Agora, sinta o poema de uma outra forma. Ouça o podcast gravado em 2012 e publicado no audioblog "Estúdio Raposa". O endereço é:

<http://www.estudioraposa.com/index.php/15/01/2012/fernando-pessoapoeta-fingidor/>. Acesso 25 jan., 2017.

b) Você está lembrado que, desde o início, temos comentado sobre os podcasts? A partir do que já estudou até aqui, escreva o que você entende por podcast.

c) Contudo, na atividade número 6 apareceu um termo diferente: "audioblog". Você sabe o que é um audioblog? Realize uma pesquisa sobre alguns termos da área da tecnologia: blog, audioblog, podcast. Traga suas anotações para a sala de aula e troque informações com toda a turma.

d) O poema "Poeta fingidor" se encaixaria em qual modalidade de poemas (cinquina, biopoema, quadra) estudados por nós? Comente sua resposta. 
7) Diferentemente das quadras, os biopoemas e as cinquinas não apresentam rimas. Mas, possuem suas especificidades que contribuem para a construção toda especial e diferente desses poemas. Veja a seguir uma breve explanação sobre cada um deles. Depois você irá completar a coluna que está em azul.

Cinquina:

\begin{tabular}{|l|l|}
\hline $\begin{array}{l}\text { Linha } 1 \text { uma palavra (substantivo) que é } \\
\text { também o título do poema. }\end{array}$ \\
\hline $\begin{array}{l}\text { Linha } 2 \text { = duas palavras (adjetivos) com o intuito } \\
\text { de descrever o título. }\end{array}$ \\
\hline $\begin{array}{l}\text { Linha } 3 \text { = três palavras (verbos, muitas vezes } \\
\text { escritos no gerúndio) que contam ao leitor um } \\
\text { pouco mais sobre o tema do poema. }\end{array}$ \\
\hline $\begin{array}{l}\text { Linha } 4 \text { quatro ou mais palavras que } \\
\text { demonstram emoções com relação ao tema do } \\
\text { poema, formando uma frase. }\end{array}$ \\
\hline $\begin{array}{l}\text { Linha } 5=\text { uma palavra - sinônimo para o título } \\
\text { ou muito parecido com ele. }\end{array}$ \\
\hline
\end{tabular}

Biopoema:

\begin{tabular}{|l|l|}
\hline $\begin{array}{l}\text { Linha } 1=\text { Primeiro nome da pessoa sobre } \\
\text { quem irá falar }\end{array}$ & \\
\hline $\begin{array}{l}\text { Linha } 2=\text { Que é ... (3 adjetivos que descrevam } \\
\text { a pessoa) }\end{array}$ & \\
\hline $\begin{array}{l}\text { Linha } 3=\text { Que é o... (irmão, irmã, amiga } \ldots . . \\
\text { de...) }\end{array}$ & \\
\hline Linha $4=$ Que ama ... (3 palavras) & \\
\hline Linha 5 = Que sente ... ( 3 palavras) & \\
\hline Linha 9 = Que precisa de ... (3 palavras) & \\
\hline Linha $10=$ Que tem medo de ... (3 ideias) & \\
\hline Linha $11=$ Que gostaria de ... (3 ideias) & \\
\hline Linha $12=$ Que compartilha ... (3 ideias) & \\
\hline Linha $13=$ Que é... (3 substantivos) & \\
\hline Linha $14=$ Que mora em... (1 palavra - local) & \\
\hline Linha $15=$ Sobrenome da pessoa & \\
\hline
\end{tabular}

8) Temos, a seguir, dois poemas. Sua tarefa será escrever cada verso de cada poema, na segunda coluna dos quadros acima, obedecendo às especificações apresentadas na primeira coluna, de modo que o poema tenha a poesia que se almeja. 

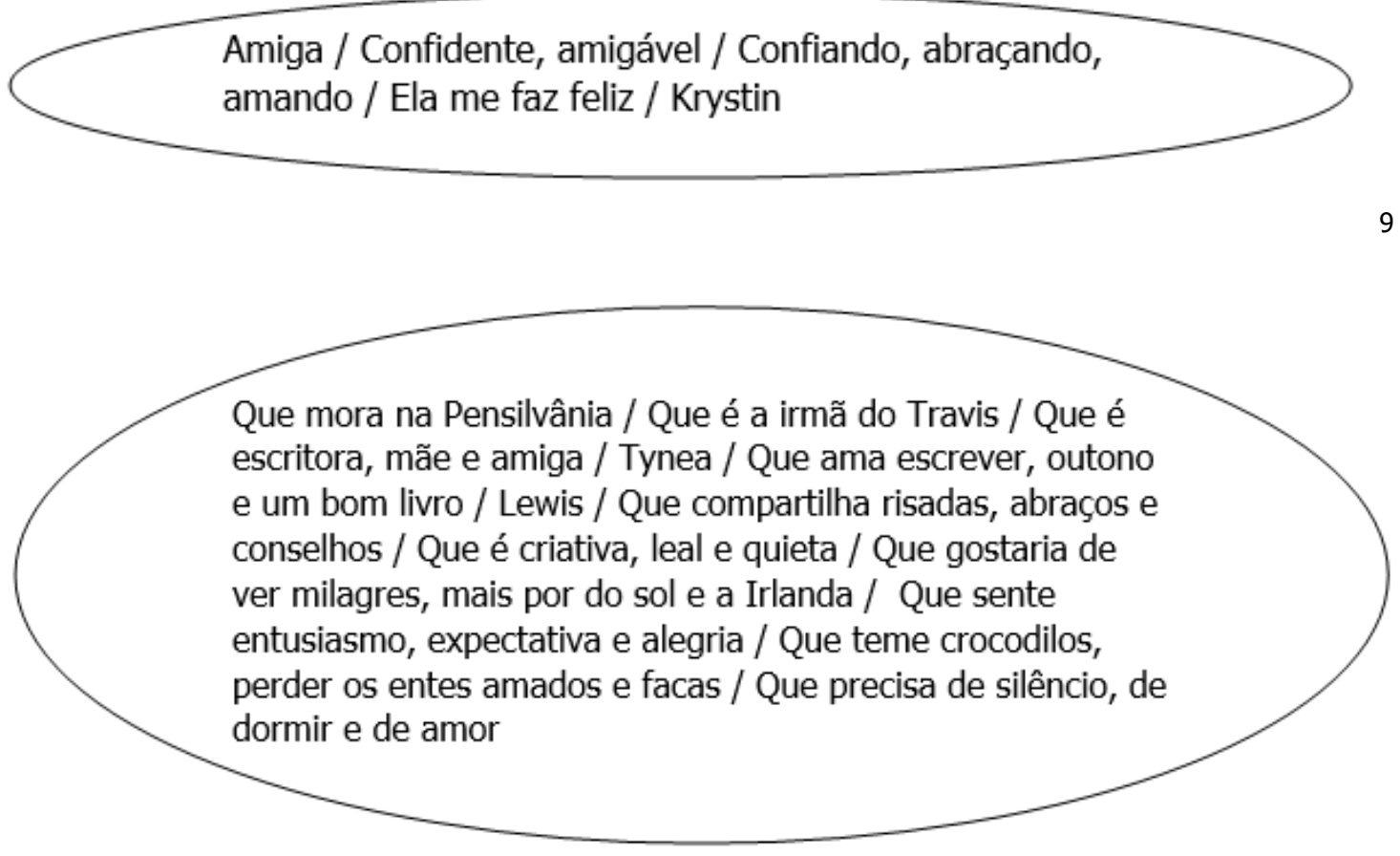

10

Módulo 4

Trabafhando com a finguagem dos poemas...

\section{Leia o texto a seguir e explique em que sentidos a palavra "pneu" é empregada.}

${ }^{9}$ Esse poema foi escrito originalmente em língua inglesa "Krystin / Confidant, friendly / Trusting, hugging, loving / She makes me happy / Friend"e está disponibilizado em <https://www.poetrysoup.com/poem/friend_23407>. Acessoem: 28 jan. 2017.

${ }^{10}$ Esse poema foi escrito originalmente em língua inglesa: "Tynea/Who is creative, loyal and quiet/Who is the sister of Travis/Who loves writing, fall, and a good book/Who feels excitement, anticipation and joy/Who needs quiet, sleep and love/Who fears crocodiles, losing loved ones, and knives/Who would like to see miracles, more sunrises and Ireland/Who shares laughs, hugs and advice/Who is a writer, mother and friend Who is a residente of Pennsylvania/Lewis" e está disponibilizado em: <http://forums.familyfriendpoems.com/topic.asp?TOPIC_ID=66411>. Acesso em: 28 jan. 2017 


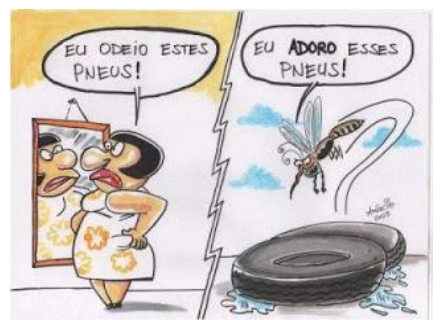

Fonte: <http://prevestibularmaua.blogspot.com.br/2013/05/denotacao-e-conotacao.html>. Acesso em: 10 jan. 2017.

2. Assista ao vídeo "Denotação e conotação", disponível em: <https://www.youtube.com/watch?v=EPCumfKk9Fk>. Acesso em: 19 abr. 2017. Em seguida, escreva se a palavra pneu, no texto acima, apresenta-se no sentido denotativo ou conotativo.

3. Dorival Cayme, poeta popular brasileiro, compôs várias músicas inspirado pelos hábitos, costumes e tradições do povo baiano. Dentre essas composições, trazemos um excerto da canção Roda Pião. Após fazer a leitura, responda às questões que seguem.

RodaPião (Dorival Cayme)

Quando a gente é criancinha

Canta quadras pra brincar

Quando fica gente grande

Ouve quadras a chorar

[...]

Passa de um lado pro outro, ô pião

Roda, pião

Bambeia, ô pião

Também a vida da gente

É um pião sempre a rodar

Um pião que também pára

Quando o tempo o faz cansar

Disponível em: <http://www.musicasamba.com/dorival-caymmi/eu-vou-paramaracangalha/roda-piao/>. Acesso em: 19 abr. 2017.

a) Uma das principais características do poema é a presença de rimas. Copie do excerto acima as rimas realizadas.

b) Analisando a primeira e a última estrofe, em quais versos aparecem as rimas?

c) A partir das respostas dadas anteriormente, como você explicaria o que são rimas? 
4. Leia a explicação sobre rimas. Depois volte ao exercício C e veja se sua resposta está adequada ou se precisa melhorá-la.

Considera-se que a rima em muito demarca o ritmo do poema, conferindo-lhe a musicalidade e a melodia necessárias. A rima se caracteriza pela semelhança sonora das palavras, podendo ser retratada no final ou no interior dos versos e em posições variadas. As rimas podem ser:

Rimas alternadas (ou cruzadas): Combinam-se alternadamente, seguindo o esquema ABAB.

Rimas emparelhadas (ou paralelas): Combinam-se de duas em duas, seguindo o esquema AABB.

Rimas interpoladas (ou intercaladas): Combinam-se numa ordem oposta, seguindo o esquema ABBA.

Rimas encadeadas: Quando as palavras que rimam se situam no fim de um verso e no início ou meio do outro.

Rimas mistas (ou misturadas): Quando apresentam outras combinações e posições na estrofe, sem esquemas fixos.

Versos brancos (ou soltos): São versos que não rimam com nenhum outro verso.

(Adaptado de: < https://www.normaculta.com.br/classificacao-de-rimas/> Acesso em: 20 abr. 2017.)

5. Leia novamente o texto do exercício 1 e diga que tipo de rimas ele apresenta.

6. Releia os poemas do módulo anterior (a cinquina e o biopoema), analise-os em relação às rimas e escreva como eles se classificam.

Gontinuando com a produção escrita...

1) Você está lembrado que produziu um poema no início dessa unidade? Ele será agora devolvido a você para que possa, depois de tudo o que estudamos, analisar a sua própria escrita. A fim de ajudálo nessa tarefa, você e seus amigos irão construir, juntamente com seu professor, uma tabela onde deverão incluir alguns pontos a serem observados quando forem ler e analisar seus textos. A tabela já foi iniciada por nós. Agora, é com vocês... 


\begin{tabular}{|l|l|l|l|}
\hline \multicolumn{5}{|l|}{ LISTA DE CONSTATAÇÃo } \\
\hline Elementos a serem observados & Sim & Não & Parcialmente \\
\hline 1. O tema está adequado ao que foi proposto? & & & \\
\hline $\begin{array}{l}\text { 2. A minha produção seguiu um dos subgêneros } \\
\text { estudados (quadra, cinquina, biopoema)? }\end{array}$ & & & \\
\hline 3. & & & \\
\hline 4. & & & \\
\hline
\end{tabular}

2) Pronto! Com a tabela completa vocês passarão para a próxima tarefa, a qual pode ser feita da seguinte forma:

A) Sentados em dupla, cada colega analisa o texto do outro e anota o que acha necessário mudar, o que acha que está bom.

B) Na sequência, os textos são devolvidos e, após ler as análises do colega, você analisa seu texto e faz as anotações que achar necessárias.

3) Com base nessas análises e também a partir dos estudos realizados, você irá reescrever seu texto, para deixá-lo ainda melhor! Terminando, entregue as duas versões a seu professor (identifique-as como:"Primeira versão" e "Segunda versão"). Ele irá ler e devolvê-las em um outro momento para que você possa, finalmente, terminar sua grande obra poética!

Trabafhando com a finguagem dos poemas...

\section{1) Vamos falar sobre os sons e as suas combinações?}

a) Antes, assistam ao vídeo: Aliteração e Assonância, no seguinte endereço:

<https://www.youtube.com/watch?v=1uYkdiAeEIs>

b) No vídeo, a discussão é sobre as figuras de linguagem aliteração e

assonância. A partir do que foi explicado no vídeo, escreva o que você

entendeu por aliteração e por assonância.

c) A aliteração possui grande importância na produção de poemas, porque ela consiste na repetição de sons. Veja outro exemplo:

"Olha a bolha d'água

no galho! 
Olha o orvalho!"

(Cecília Meireles)

Agora, é sua vez: quais são os sons que se repetem no poema acima?

d) Observe estes outros exemplos e responda: quais são as aliterações presentes nos textos? Essas repetições de sons possuem algum efeito de sentido? Possuem um objetivo relacionado à mensagem? (Leia em voz alta para verificar a produção dos sons)

I. O rato roeu a roupa do rei de $\mathrm{Roma.}$

II. Três pratos de trigo para três tigres tristes.

e)Observe o texto seguinte e analise se há assonância. Justifique sua resposta.

"Sou um mulato nato no sentido lato

mulato democrático do litoral."

(Caetano Veloso)

\section{Existem outras figuras de linguagem que são frequentemente utilizadas em poemas. Observe:}

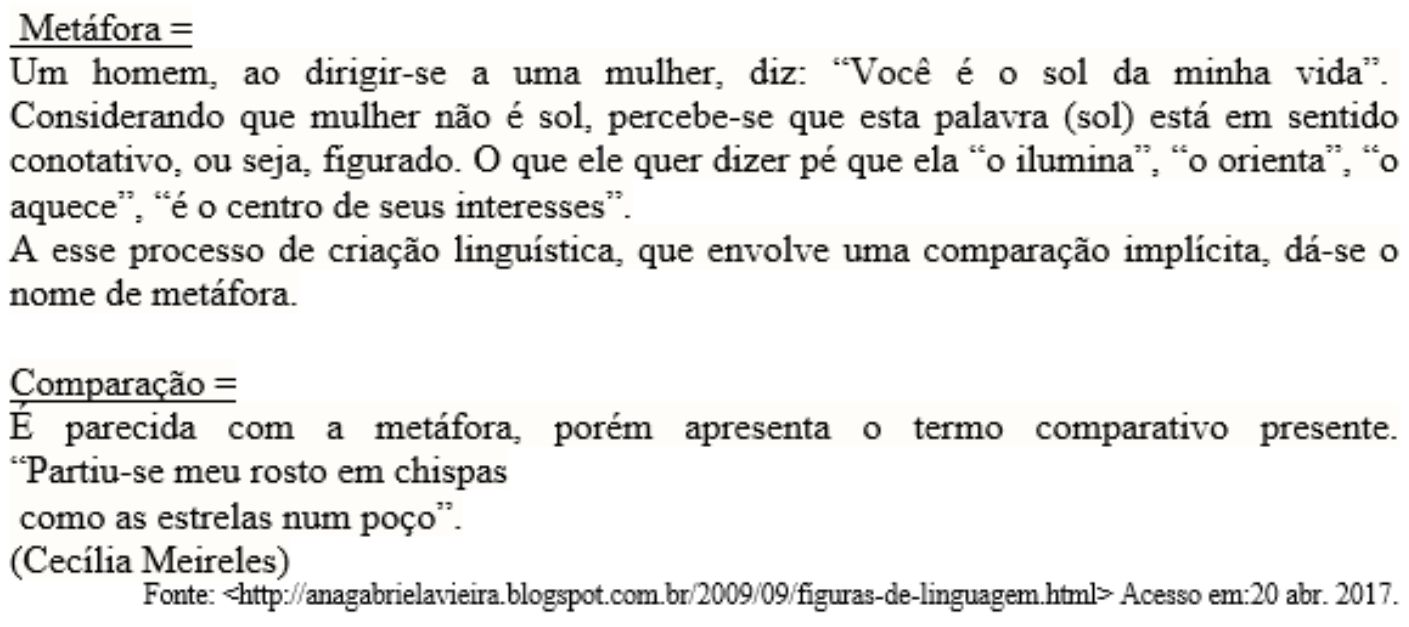

\section{Leia o poema "O leão" e circule o verso onde ocorre comparação.}

O Leão

Leão! Leão! Leão!

Rugindo como o trovão

Deu um pulo, e era uma vez 
Um cabritinho montês.

Leão! Leão! Leão!

És o rei da criação!

Tua goela é uma fornalha

Teu salto, uma labareda

Tua garra, uma navalha

Cortando a presa na queda

$[\ldots]$

(Vinícius de Moraes. A arca de Noé: poemas infantis. São Paulo: Companhia das Letras, 1991.)

\section{Girassol - Ira}

\section{Há metáforas no excerto acima? Justifique sua resposta.}

\section{Leia atentamente a explicação a seguir:}

Para escrever ou falar de alguém, de um passeio, de uma viagem, de um objeto, de uma situação que aconteceu no dia a dia, utilizamos palavras que venham a nomear o elemento central de nossa história/fato/ideia, palavras que vão descrever/qualificar estes elementos e palavras que vão contar/expressar a ação e estados emocionais e físicos que desejamos expor. Para nomear as coisas, utilizamos substantivos. Para descrever estes substantivos, utilizamos adjetivos. E para expressar cada coisa que fizemos nessa viagem, nesse passeio, utilizamos os verbos. Essas palavras são chamadas de classes gramaticais e devemos compreender a existência delas para compor nossos poemas.

\section{Para iniciar nossa reflexão, leia o poema e responda as questões:}

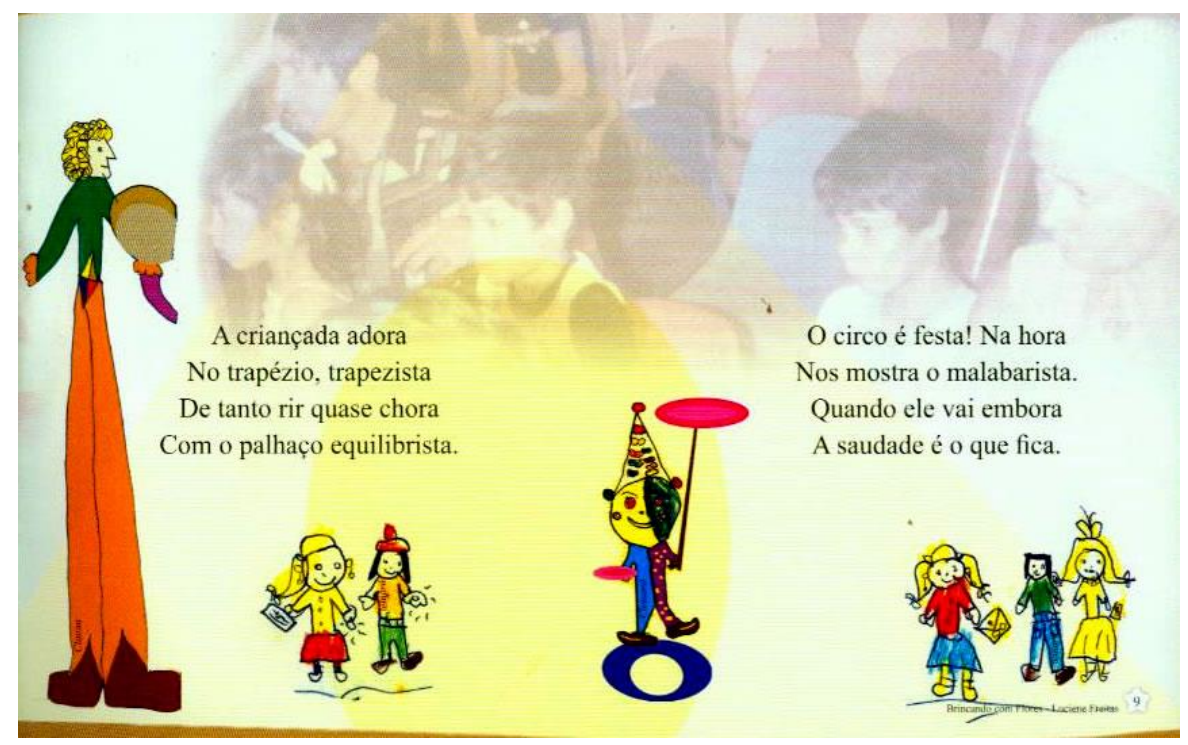


Fonte: <http://www.antoniomiranda.com.br/poesia_infantil/cecilia_meireles.html>. Acesso em: 06 fev. 2017.

a) Qual é a história que está sendo contada neste poema?

b) Com base na sua resposta, escolha 4 palavras que considera essenciais para que você compreenda a história.

c) Das 4 palavras que escolheu, quais delas nomeiam pessoas/objetos/situações e quais indicam ações?

d) Pensando sobre os três diferentes formatos de poemas estudados nesta Unidade, em qual deles poderia se encaixar o poema acima. Justifique sua resposta.

\section{Trabalharemos, agora com um poema escrito por um dos maiores poetas brasileiros: "Carlos Drummond de Andrade". Mas antes, saiba um pouquinho sobre ele:}

Carlos Drummond de Andrade, cronista, jornalista, funcionário público e, principalmente, poeta. Um dos maiores nomes da literatura brasileira apostou em versos livres e linguagem objetiva nas suas obras. Drummond, além de poemas, escreveu livros em prosa e alguns de temática infantil.

O mineiro morou no Rio de Janeiro por muitos anos, mas a terra natal, Itabira, sempre esteve presente nos seus versos. O poeta ainda trata da questão da existência, do individualismo e do fazer poético. Em uma fase mais social, apresenta versos que mostram solidariedade e desejo de transformação.

$[\ldots]$

Disponivel em: <http://educacao.globo.com/literatura/assunto/autores/carlos-drummond-de-andrade.html> Acesso em:20 abr.2017

8. Assista à declamação do poema "No meio do caminho" de Carlos Drummond de Andrade. Para isso acesse o seguinte endereço: <https://www.youtube.com/watch?v=sO6TySzyygE>. Acesso em: 20 abr. 2017.

Em seguida, resolva as atividades propostas. 
A) De todos os idiomas apresentados no vídeo, quais você ouviu pela primeira vez? Qual chamou mais a sua atenção e por quê?

B) Pensando em nosso contexto sócio-histórico, por que você diria que o vídeo encerrou a declamação com a língua tupi?

C) O poema "No meio do caminho" apresenta dois substantivos que assumem papel fundamental na mensagem que 0 autor quis nos transmitir. Que substantivos são esses?

D) Esses dois substantivos foram usados em sentido:

I ( ) conotativo

II( ) denotativo

E) O que representam esses dois substantivos?

F) O poema é lido como lemos uma receita? Lemos um email da mesma forma que lemos um poema? Qual a sua opinião sobre essas questões?

9. Leia as informações que seguem a respeito da declamação de poemas. 
A poesia é uma das mais completas formas de expressão artística. Ela nos fala de sentimentos, de acontecimentos, de pessoas, de lugares, enfim nos fala de conhecimentos. A declamação é a verbalização ou interpretação da poesia, ou seja: o declamador dá voz ao autor da poesia. Ao pretender declamar, uma pessoa tem que tomar alguns cuidados, sem os quais corre o risco de cometer erros, que podem comprometer a qualidade artística de seu trabalho.

COMPREENSÃO

O declamador deve compreender perfeitamente o que está dizendo, isto é conhecer o poema, saber o que significa cada termo do poema, bem como sua correta pronúncia. Também dever entender a pontuação, para poder fazer as pausas adequadamente.

INTERPRETAÇÃO

É na interpretação que o declamador tem a oportunidade de mostra a sua arte. A interpretação deve ser comedida, porém não pode ser pobre.

IMPOSTAÇÃO DE VOZ

Impostação de voz é a interpretação de um poema, sob o aspecto da voz. Deve ser observado com muito cuidado o texto, para não se dramatizar passagens neutras, ou não apresentar de maneira neutra passagem dramáticas.

IDENTIFICAÇÃO DO POEMA

Necessariamente tem de ser indicados o nome de seu autor e o título do poema, antes de iniciar a declamação. Porém não os dizer já declamando.

AGRADECIMENTO

Alguns declamadores ao terminar sua interpretação acrescentam agradecimentos ou a expressão: "Tenho dito". Isso não cabe. Para indicar que terminou sua recitação o declamador deve usar um pequeno estratagema, que pode ser diminuir o tom da voz, levantá-lo, se couber, fazer um gesto de cabeça ou de mãos.

Adaptado de : < http://recantodasletras.uol.com.br/artigos/1250846>Acesso em: 21 abr. 2017) 
10. Agora, escolha um dos poemas estudados nesta Unidade e prepare a declamação dele. Essa atividade pode ser feita em dupla ou individualmente. Seu professor irá marcar um dia para essas apresentações em sala de aula. Capriche!

\section{Finafizando a produção escrita...}

Muito bem! Estamos chegando ao final! Seu professor Ihe entregará sua segunda versão do poema. Você deverá olhar para ele, com muito carinho, mais uma vez. Para isso, use novamente a lista de constatação e observe também os recadinhos e sugestões que seu professor deixou em seu texto. A partir disso, você irá para a produção final. Pense! Mude o que achar necessário! Acrescente 0 que falta para deixar seu poema ainda melhor! Reescreva-o e treine a sua leitura. Não se esqueça da emoção, da entonação, das pausas... enfim, tudo que uma declamação requer.

Em uma aula previamente marcada, você e seus colegas irão declamar seus poemas... Mas se acalme! Nesse momento, será somente para a sua turma. Isso será como um treino para que vocês possam, posteriormente, gravar o podcast.

Combine também com seu professor, o que será dito antes da declamação do poema. Afinal, é necessária uma apresentação do podcast.

Produção finas: $\mathscr{P}_{\text {ubficar os podcasts }}$

1) Agora que vocês já produziram seus textos, já estudaram a respeito de como utilizar a entonação e os recursos orais e já conheceram a mídia podcast, vamos iniciar a gravação dos podcasts e publicá-los no blog da turma.

a) A primeira coisa a fazer é realizar a gravação individual dos podcasts. Isso será realizado com a mediação de seu professor por meio do Skype - com o auxílio do aplicativo Ifree Skype Recorder, cuja função é, justamente, permitir que o Skype grave os áudios completos.

b) Agora, para ouvir, receber os podcasts, você poderá acessar o Feed ou ir direto ao blog no qual seu professor publicará todos os podcasts da turma.

Tutorial: blog epodcasts 
Para auxiliar no processo da criação do blog e do podcast, criamos um breve tutorial de como realizar o passo a passo de cada um dos suportes.

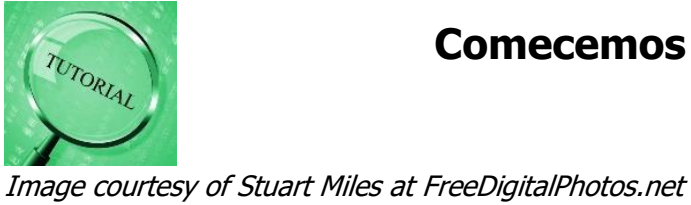

$\checkmark$ Após a escolha do tema, o autor do podcast deve escolher o seu título. É interessante

que o autor pesquise se já não existe um podcast com o mesmo nome, caso contrário a plataforma não aceitará a publicação. Para isso, o autor só necessita de um computador de um microfone. Existem alguns fones que possuem microfones acoplados. Contudo, se for um ambiente silencioso, o próprio microfone do notebook supre tal necessidade.

$\checkmark$ Para realizar a gravação dos arquivos de áudio, o usuário deve possuir em seu computador um programa que permita tal realização. A sugestão que fazemos em nosso trabalho é do iFree Skype Recorder, um programa associado ao Skype que permite, inclusive, que várias pessoas possam gravar o áudio em conjunto, por meio da conexão de grupos e pessoas. Ainda que não seja o nosso caso, o programa é de fácil uso, 0 que auxilia a gravação.

$\checkmark$ Dentro do programa citado, há a necessidade de inserir o login e a senha do usuário do Skype e, após isso, na página inicial, há duas opções de seleção: gravar e pausar. Ao clicar na opção gravar, automaticamente, o áudio começa a ser produzido, podendo o usuário, inclusive, interromper sua gravação e continuar do mesmo local.

$\checkmark$ Ao término da gravação, o arquivo ficará disponível em uma pasta automática no computador, local que o autor deverá acessar para buscar seu arquivo para "hospedar", ou seja, salvar seu podcast num site que faça esse tipo de seleção.

$\checkmark$ Existem vários sites hospedeiros, mas optamos pelo Soundcloud porque, além de ser gratuito, este hospedeiro possui aplicativos, inclusive, para celular e que possui fácil acesso.

$\checkmark$ Para salvar o arquivo, o usuário precisa se cadastrar e localizar a opção "upload de arquivos". Pronto, seu arquivo de áudio está hospedado na internet. Tendo o arquivo de áudio produzido, agora, o autor deve publicar seu texto. Para isso, optamos pelo blog enquanto local de divulgação e suporte para os podcasts.

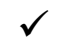

Antes da publicação, é necessário que o blog seja criado. 


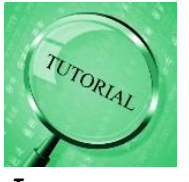

\section{Criação do BLOG:}

Image courtesy of Stuart Miles at FreeDigitalPhotos. net

$\checkmark$ Por possuir um fácil acesso, sugerimos a criação de um blog da plataforma Blogger, que é o mais utilizado no Brasil <https://www.blogger.com>. Para isso, o usuário precisa utilizar seu e-mail para cadastro. Após preencher os dados do usuário, algumas opções podem ser realizadas: título do blog, seleção de planos de fundo, imagens da página inicial, entre outras configurações que tornem a página mais bonita ou mais adequada ao perfil do usuário.

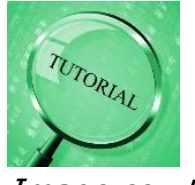

\section{Publicação do PODCAST:}

Image courtesy of Stuart Miles at FreeDigitalPhotos.net

$\checkmark$ Com o blog criado, agora vem o momento da publicação do podcast. Para isso, tendo em vista o modelo de blog do blogger, o autor deve selecionar uma "nova postagem", colocar informações como título e resumo do podcast e, por fim, inserir a página do site hospedeiro com o arquivo que foi "salvo". Ao clicar em finalizar postagem, o blog disponibiliza o podcast criado e fica disponível para ser acessado.

\section{Considerações Finais}

Ao longo da elaboração desta proposta, pudemos perceber que o trabalho com a tecnologia é árduo, contudo, possível. Permitir o alinhamento entre teoria e prática é um caminho necessário para todas as práticas de ensino-aprendizagem. No que tange ao ensino de línguas, esse trajeto torna-se uma realidade na vida do professor que, dentro de uma concepção interacionista de linguagem, assume papel de mediador do conhecimento e, principalmente, investiga e ensina a linguagem de maneira reflexiva.

Nesse sentido, nos permitimos refletir que a proposta apresentada, voltada ao $6^{\circ}$ ano do ensino fundamental, consente alicerçar os conhecimentos escolares às práticas cotidianas dos alunos que, conforme já apontado, sofre 
bruscamente a mudança dos anos iniciais para os anos finais do ensino fundamental. Dessa forma, permitir que eles aprendam e consigam refletir sobre suas práticas sociais, seu conhecimento linguístico e, principalmente, vivenciem a linguagem mediados pela mídia podcast, é propiciar que eles possam - ao longo de sua jornada escolar e não escolar- reconhecerem-se como parte integrante desse mundo tecnológico.

Uma vez que tais sujeitos-discentes são considerados nativos digitais, o trabalho mediado por recursos tecnológicos e midiáticos permite estabelecer uma relação efetiva entre prática social - escola, que, de forma ampla, vem sendo o grande enigma da prática docente:inserção de objetos e recursos digitais em sala de aula.

Reitera-se a importância de tal proposta por meio do envolvimento efetivo dos alunos em práticas orais que integram os demais eixos de ensino leitura, escrita e análise linguística - valorizando o diálogo entre as crianças/adolescentes e permitindo que elas possam se expressar por meio das diversas linguagens que permeiam sua prática social.

Ainda, o uso de uma ferramenta digital garante o estabelecimento de relações entre o cotidiano dos alunos e o processo de ensino-aprendizagem construído por meio da escola, o que se aproxima das propostas dos letramentos, digital ou não.

\section{Referências}

BAKHTIN, Mikhail Mikhailovich. Estética da criação verbal. Tradução de Maria Emsantina Galvão G. Pereira. Revisão da tradução Marina Appenzellerl. 2. ed. São Paulo: Martins Fontes, 1997.

BEATO-CANATO, Ana Paula Marques. O desenvolvimento da escrita em língua inglesa com o uso de sequências didáticas contextualizadas em um projeto de troca de correspondências. Tese. (Doutorado em Estudos da Linguagem) Universidade Estadual de Londrina. Londrina, PR, 2009. Disponível em: <http://www.bibliotecadigital.uel.br/document/?code=vtls000151181\&print =y>. Acesso em: 04 mar. 2014. 
BRASIL. Ministério da Educação - Secretaria de Educação Fundamental. Parâmetros Curriculares Nacionais: Língua Portuguesa - $1^{\circ}$ e $2^{\circ}$ Ciclos do Ensino Fundamental. Brasília: MEC/SEF, 1997.

BRONCKART, Jean Paul. Atividade de linguagem, textos e discursos: por um interacionismo sócio-discursivo. Tradução: Anna Raquel Machado, Péricles Cunha. São Paulo: EDUC, Ed. 2, 2012.

BRONCKART, Jean Paul. O agir nos discursos: das concepções teóricas às concepções dos trabalhadores. Trad. Anna Rachel Machado, Maria de Lourdes Meirelles Matencio. Campinas, SP: Mercado das Letras, 2008.

COSSON, Rildo. Letramento literário: teoria e prática. São Paulo: Contexto, 2006.

CRISTOVÃO, Vera Lúcia Lopes; STUTZ, Lídia. Sequências didáticas: semelhanças e especificidades no contexto francófono como L1 no contexto brasileiro como LE. In: SZUNDY, Paula Tatianne Carréra et al (Orgs.). Linguística Aplicada e Sociedade. Ensino e Aprendizagem de Línguas no Contexto Brasileiro. Campinas, SP. Pontes Editores, 2011.

CRISTOVÃO, Vera Lúcia Lopes. Para uma expansão do conceito de capacidades de linguagem. In: BUENO, Luzia; LOPES, Maria Angela Paulino Teixeira.; CRISTOVÃ̃, Vera Lúcia Lopes. (Org.) Gêneros textuais e formação inicial: uma homenagem à Malu Matêncio. 1.ed. Campinas, SP: Mercado das Letras, 2013.

DIONÍSIO, Angela Paiva. Gêneros textuais e multimodalidade. In: KARWOSKI, Acir Mário et al. (Org.). Gêneros textuais: reflexões e ensino. Palmas:

Kaygangue, 2011.

DOLZ, Joaquim; NOVERRAZ, Michele; SCHNEUWLY, Bernard. Sequencias didáticas para o oral e a escrita: apresentação de um procedimento. In: SCHNEUWLY, Bernard.; DOLZ, Joaquim .et.al. Gêneros orais e escritos na escola. Campinas: Mercado de Letras, Ed.2, 2010.

DOLZ, Joaquim; SCHNEUWLY, Bernard. Gêneros e progressão em expressão oral e escrita - elementos para reflexões sobre uma experiência suíça (francófona). In: SCHNEUWLY, Bernard; DOLZ, Joaquim et.al. Gêneros orais e escritos na escola. Campinas: Mercado de Letras, Ed.2, 2010.

FERRARA, Sue. What are bio poems? s/d. Disponível em < http://education.seattlepi.com/bio-poems-5438.html>. Acesso em: 21 jan. 2017. 
FERRARINI, Marlene Aparecida. O gênero textual conto de fadas didatizado para o ensino de produção escrita em língua inglesa. Dissertação (Mestrado em Estudos da Linguagem) - Universidade Estadual de Londrina. Londrina, PR, 2009. Disponível em:<http://www.livrosgratis.com.br/arquivos_livros/cp125679.pdf>. Acesso em: 04 mar. 2014.

FREIRE, Eugenio Paccelli Aguiar. Podcast na educação brasileira: natureza, potencialidade e implicações de uma tecnologia da comunicação. Natal, 2013. Tese (Doutorado em Educação). Centro de Ciências Sociais Aplicadas, Universidade Federal do Rio Grande do Norte.

- Construindo um modelo de referência à participação ativa dos Sujeitos em projetos educativos em ambiente on-line. Natal, 2010. $214 \mathrm{p}$. Dissertação (Mestrado em Educação). Centro de Ciências Sociais Aplicadas, Universidade Federal do Rio Grande do Norte.

GERALDI, João Wanderley. Portos de passagem. São Paulo: Martins Fontes, 1984.

KLEIMAN, Angela Bustos. Linguagem e formação do professor: apontamentos de uma travessia (em ensaio em homenagem a Malu Matêncio). In: BUENO, Luzia; LOPES, Maria Angela Paulino Teixeira.; CRISTOVÃO, Vera Lúcia Lopes. (Org.) Gêneros textuais e formação inicial: uma homenagem à Malu Matêncio. 1.ed. Campinas, SP: Mercado das Letras, 2013.

LANFERDINI, Priscila Azevedo da Fonseca. O trabalho (agir) docente no processo coletivo de planejamento e elaboração de uma sequência didática para o ensino de língua inglesa. Dissertação (Mestrado em Estudos da Linguagem) - Universidade Estadual de Londrina, PR, 2012. Disponível em: <http://www.bibliotecadigital.uel.br/document/?code=vtls000177959>. Acesso em: 20 mar. 2014.

LÉVY, Pierry. A nova relação com o saber. In: LÉVY, Pierry. Cibercultura. Tradução: Carlos Irineu da Costa. São Paulo: Editora 34, 1999. p. 159-170.

MACHADO, Anna Rachel. A perspectiva interacionista sociodiscursiva de Bronckart. In: MEURER, José Luiz; BONINI, Adair; MOTTA-ROTH, Desiree. (Orgs.).Gêneros: teorias, métodos, debates. São Paulo: Parábolas Editorial, 2005. p. 237-259.

NASCIMENTO, Roseli Gonçalves. do; BEZERRA, Fábio Alexandre Silva; HEBERLE, Viviane Maria. Multiletramentos: iniciação à análise de imagens. Linguagem \& ensino, Pelotas, v.14, n. 2, p. 529-552, 2011. 
PARANÁ. Secretaria de Estado da Educação. Superintendência da Educação. Departamento de Educação Básica. Diretrizes Curriculares de Língua Portuguesa. Curitiba, 2008.

PASQUIER, Auguste; DOLZ, Joaquim. Um decálogo para ensinar a escrever. Cultura y Educación, n. 2, p. 31-41, 1996. Disponível em:

<http://pt.scribd.com/doc/65966212/Um-decalogo-para-ensinar-a-escrevertraducao-Roxane-Rojo >. Acesso em: 14 out. 2013.

PETRECHE, Celia Regina Capellini. A sequência didática nas aulas de língua inglesa do ensino médio e o desenvolvimento de capacidades de linguagem. Dissertação (Mestrado em Estudos da Linguagem) - Universidade Estadual de Londrina. Londrina, PR, 2008. Disponível em: < http://www.bibliotecadigital.uel.br/document/?code=vtls000144668>. Acesso em: 20 abr. 2014.

PONTARA, Claudia Lopes. Gêneros textuais e sequência didática propiciando um ensino significativo de análise linguística e expressão escrita em língua inglesa. Dissertação (Mestrado em Estudos da Linguagem) __Universidade Estadual de Londrina, Centro de Letras e Ciências Humanas, Programa de Pós-Graduação em Estudos da Linguagem, 2015.Disponível em <file:///C:/Users/Win7/Downloads/Pontara_Claudia_L_Me_2015\%20(3).pdf>. Acesso em: 19 abr. 2017.

LENHARO, Rayane Isadora. Participação social por meio da música e da aprendizagem de língua inglesa em um contexto de vulnerabilidade social. Dissertação (Mestrado em Estudos da Linguagem). Universidade Estadual de Londrina, Centro de Letras e Ciências Humanas, Programa de Pós-Graduação em Estudos da Linguagem, 2016.

PRENSKY, Mark. Nativos digitais imigrantes digitais. Tradução: Roberta de Moraes Jesus de Souza .Versão original: Digital Natives Digital Immigrants. On the Horizon, NCB University Press, v. 9, n. 5, 2001, p. 1-6. Disponível em: <https://docs.google.com/document/d/1XXFbstvPZIT6Bibw03JSsMmdDknwjNc TYm7j1a0noxY>. Acesso em: 15 out. 2016.

PRIMO, Alex Fernando Teixeira. Para além da emissão sonora: as interacções no podcasting. Intertexto, Porto Alegre, 2005. Disponível em: <http://www.lume.ufrgs.br/handle/10183/26568>. Acesso em: 27 jan. 2016.

RIBEIRO, Ana Elisa. Letramento digital: um tema em gêneros efêmeros. Revista da ABRALIN, Belém, v. 8, n. 1, p. 15-38, 2009. 
ROJO, Roxane. Pedagogia dos multiletramentos: diversidade cultural e de linguagens na escola. In: ROJO, Roxane; MOURA, Eduardo. (Orgs.). Multiletramentos na escola. São Paulo: Parábola Editorial, 2012.

SCHNEUWLY, Bernard; DOLZ, Joaquim.et al. Gêneros orais e escritos na escola. Campinas: Mercado das Letras. Ed.2, 2010.

SCHNEUWLY, Bernard. DOLZ, Joaquim. Os gêneros escolares - das práticas de linguagem aos objetos de ensino. In: SCHNEUWLY, Bernard; DOLZ, Joaquim. et al. Gêneros orais e escritos na escola. Campinas: Mercado das Letras. Ed.2, 2010.

SCHNEUWLY, Bernard. Gêneros e tipos de discursos: considerações psicológicas e ontogenéticas. In: SCHNEUWLY, Bernard; DOLZ, Joaquim. et al. Gêneros orais e escritos na escola. Campinas: Mercado das Letras. Ed.2, 2010.

SOUZA, Renata Junqueira de; COSSON, Rildo. Letramento literário: uma proposta para a sala de aula. UNESP, 2011. Disponível em:<http://acervodigital.unesp.br/handle/123456789/40143>. Acesso em: 13 jan.2017.

SOUSA, Henrique Eduardo de. Letramento literário na escola: o poema na aula de língua portuguesa no ensino médio / Henrique Eduardo de Sousa. 2013. Tese (doutorado) - Universidade Federal do Rio Grande do Norte. Centro de Ciências Humanas, Letras e Artes. Departamento de Letras, 2013. Disponível em:

<https://repositorio.ufrn.br/jspui/bitstream/123456789/16381/1/HenriqueES_T ESE.pdf > . Acesso em: 10 jan. 2017

STUTZ, Lidia. Sequências didáticas, socialização de diários e autoconfrrontação: instrumentos para a formação inicial de professores de inglês. Tese (Doutorado em Estudos da Linguagem) - Universidade Estadual de Londrina. Londrina, PR, 2012. Disponível em:<http://www.bibliotecadigital.uel.br/document/?code=vtls000178953>. Acesso em: 13 jan. 2015.

VEDOVATO, Luciana. O gênero poema em sala de aula: Uma proposta de estudo e transposição didática. Londrina, 2008. Disponível em:

<file:///C:/Users/User/Downloads/Vedoato_Luciana_Me-2008.pdf>. Acesso em: 07 jan. 2017.

PERFEITO, Alba Maria ; VEDOVATO, Lúcia. O gênero poema em sala de aula: um estudo na perspectiva bakhtiniana. Línguas \& Letras. Cascavel, v. 11 no 21 p 241-264, 2011. Disponível em:<file://C:/Users/Win7/Downloads/616022752-2-PB.pdf>. Acesso em: 07 jan. 2017. 
RADICH, Sandra Ferrari. Trovas ou quadras. 2013. Disponível em:

<http://www.recantodasletras.com.br/trovas/4322414>. Acesso em: 20 jan.2017. 